NBER WORKING PAPER SERIES

\title{
FEDERAL GOVERNMENT DEBTS AND INTEREST RATES
}

\author{
Eric Engen \\ R. Glenn Hubbard \\ Working Paper 10681 \\ http://www.nber.org/papers/w1068 \\ NATIONAL BUREAU OF ECONOMIC RESEARCH \\ 1050 Massachusetts Avenue \\ Cambridge, MA 02138 \\ August 2004
}

An earlier draft of this paper was prepared for presentation at the NBER Macroeconomics Annual Conference in Cambridge, MA, April 2-3, 2004. We thank Bill Gale, Mark Gertler, Kevin Hassett, Thomas Laubach, Jonathan Parker, Ken Rogoff, Matthew Shapiro, and NBER conference participants for helpful comments, and Anne Moore for providing excellent research assistance with this paper. The views expressed herein are those of the author(s) and not necessarily those of the National Bureau of Economic Research.

(C)2004 by Eric Engen and R. Glenn Hubbard. All rights reserved. Short sections of text, not to exceed two paragraphs, may be quoted without explicit permission provided that full credit, including (C) notice, is given to the source. 
Federal Government Debt and Interest Rates

Eric Engen and R. Glenn Hubbard

NBER Working Paper No. 10681

August 2004

JEL No. E0, H0

\begin{abstract}
Does government debt affect interest rates? Despite a substantial body of empirical analysis, the answer based on the past two decades of research is mixed. While many studies suggest, at most, a single-digit rise in the interest rate when government debt increases by one percent of GDP, others estimate either much larger effects or find no effect. Comparing results across studies is complicated by differences in economic models, definitions of "government debt" and "interest rates," econometric approaches, and sources of data.

Using a standard set of data and a simple analytical framework, we reconsider and add to empirical evidence on the effect of federal government debt and interest rates. We begin by deriving analytically the effect of government debt on the real interest rate and find that an increase in government debt equivalent to one percent of GDP would be predicted to increase the real interest rate by about two to three basis points. While some existing studies estimate effects in this range, others find larger effects. In almost all cases, these larger estimates come from specifications relating federal deficits (as opposed to debt) and the level of interest rates or from specifications not controlling adequately for macroeconomic influences on interest rates that might be correlated with deficits.
\end{abstract}

We present our own empirical analysis in two parts. First, we examine a variety of conventional reduced-form specifications linking interest rates and government debt and other variables. In particular, we provide estimates for three types of specifications to permit comparisons among different approaches taken in previous research; we estimate the effect of: an expected, or projected, measure of federal government debt on a forward-looking measure of the real interest rate; an expected, or projected, measure of federal government debt on a current measure of the real interest rate; and a current measure of federal government debt on a current measure of the real interest rate. Most of the statistically significant estimated effects are consistent with the prediction of the simple analytical calculation. Second, we provide evidence using vector autoregression analysis. In general, these results are similar to those found in our reduced-form econometric analysis and consistent with the analytical calculations.

Taken together, the bulk of our empirical results suggest that an increase in federal government debt equivalent to one percent of GDP, all else equal, would be expected to increase the long-term real rate of interest by about three basis points, though one specification suggests a larger impact, while some estimates are not statistically significantly different from zero. By presenting a range of results with the same data, we illustrate the dependence of estimation on specification and definition differences.

Eric M. Engen

American Enterprise Institute

$115017^{\text {th }}$ Street, NW

$11^{\text {th }}$ Floor

Washington, DC 20036

eengen@aei.org
R. Glenn Hubbard

Columbia University

609 Uris Hall

3022 Broadway

New York, NY 10027

and NBER rgh1@columbia.edu 


\section{Introduction}

The recent resurgence of federal government budget deficits has rekindled debates about the effects of government debt on interest rates. While the effects of government debt on the economy can operate through a number of different channels, many of the recent concerns about federal borrowing have focused on the potential interest rate effect. Higher interest rates caused by expanding government debt can reduce investment, inhibit interest-sensitive durable consumption expenditures, and decrease the value of assets held by households, thus indirectly dampening consumption expenditures through a wealth effect. The magnitude of these potential adverse consequences depends on the degree to which federal debt actually raises interest rates.

While analysis of the effects of government debt on interest rates has been ongoing for more than two decades, there still is little empirical consensus about the magnitude of the effect, and the difference in views held on this issue can be quite stark. While some economists believe there is a significant, large, positive effect of government debt on interest rates, others interpret the evidence as suggesting that there is no effect on interest rates. Unfortunately, both economic theory and empirical analysis of the relationship between debt and interest rates have proved inconclusive.

We review the state of the debate over the effects of government debt on interest rates and provide some additional perspectives not covered in other reviews. We also present some new empirical evidence on this relationship. The paper is organized as follows. In the second section, we discuss the potential theoretical effects of government debt on interest rates, and provide what we think are some important guidelines for interpreting empirical analysis of this issue. In the third section, we look at some basic 
empirical facts about federal government debt and interest rates, review recent econometric analysis of the interaction of federal government debt and interest rates, and introduce some new analysis of this relationship. Finally, in the last section, we summarize our conclusions and briefly discuss the potential effects of government debt on the economy in general.

\section{Theory: How Might Government Debt Affect Interest Rates?}

A standard benchmark for understanding and calibrating the potential effect of changes in government debt on interest rates is a standard model based on an aggregate production function for the economy in which government debt replaces, or "crowds out," productive physical capital. ${ }^{1}$ In brief, this model has the interest rate $(r)$ determined by the marginal product of capital $(M P K)$, which would increase if capital $(K)$ were decreased, or crowded out, by government debt $(D)$. With a Cobb-Douglas production function:

$$
Y=A K^{\alpha} L^{(1-\alpha)},
$$

in which $L$ denotes labor units, $A$ is the coefficient for multifactor productivity, and $\alpha$ is the coefficient on capital in the production function, then the total return to capital in the economy $\left(M P K^{*} K\right)$ as a share of output $(Y)$ equalṣ $\alpha$ :

$$
\alpha=(M P K \times K) / Y
$$

This implies that the interest rate is determined by:

$$
r=M P K=\alpha \times(Y / K)=\alpha \times \mathrm{A} \times(L / K)^{1-\alpha} .
$$

\footnotetext{
${ }^{1}$ See Ball and Mankiw (1995), Elmendorf and Mankiw (1999), and Council of Economic Advisers (2003).
} 
If government debt completely crowds out capital, so that

$$
\partial K / \partial D=-1
$$

then an exogenous increase in government debt (holding other factors constant) causes the interest rate to increase:

$$
\partial r / \partial D=(\partial r / \partial K)(\partial K / \partial D)=\alpha \times(1-\alpha) \times\left(Y / K^{2}\right)>0
$$

(because $0<\alpha<1$ and $Y, K>0$ ).

In this theoretical framework, which is commonly used to describe the potential effects of government debt on interest rates, there are several important implications for empirical analysis of those effects. First, the level of the interest rate is determined by the level of the capital stock and, thus, by the level of government debt. It is the change in the interest rate that is affected by the government budget deficit, which is essentially equal to the change in government debt. Empirical estimates of the effect on interest rates tend to differ markedly depending on whether the deficit or debt is used (as we show later), and most empirical work uses a specification different from that implied by a this economic model; that is, the deficit is regressed on the level of the interest rate.

A model that suggests that deficits affect the level of the interest rate is a Keynesian $I S-L M$ framework where deficits increase the interest rate not only because debt may crowd out capital but also because deficits stimulate aggregate demand and raise output. However, an increase in interest rates in the short run from stimulus of aggregate demand is a quite different effect than an increase in long-run interest rates owing to government debt crowding out private capital. Moreover, as discussed by Bernheim (1987), it is quite difficult (requiring numerous assumptions about various 
elasticities) to construct a natural Keynesian benchmark for quantifying the short-term stimulus from deficits and the long-term crowding out of capital in trying to parse out the effect of government deficits on interest rates.

Second, factors other than government debt can influence the determination of interest rates in credit markets. For example, in a growing economy, the monetary authority will purchase some government debt in order to expand the money supply and try to keep prices relatively constant. ${ }^{2}$ Government debt held by the central bank does not crowd out private capital formation, but many empirical studies of federal government debt and interest rates ignore central bank purchases of government debt.

More difficult econometric problems are posed by the fact that other potentially important, but endogenous, factors are involved in the supply and demand of loanable funds in credit markets. In addition to public sector debt, private sector debt incurred to increase consumption also could potentially crowd out capital formation. Typically, measures of private sector debt or borrowing are not included in empirical studies of government debt. In a variant of a neoclassical model of the economy that implies Ricardian equivalence, increases in government debt (holding government consumption outlays and marginal tax rates constant) are offset by increases in private saving and thus the capital stock is not altered by government debt and the interest rate does not rise. ${ }^{3}$ Private sector saving is usually not included in empirical analyses of government debt and the interest rate. Also, in an economy that is part of a global capital market, increases in government debt can be offset by increases in foreign sector lending. Many empirical

\footnotetext{
${ }^{2}$ See McCallum (1984) for more discussion of this issue.

${ }^{3}$ See Bernheim (1987), Barro (1989), and Seater (1993) for discussions of the Ricardian equivalence hypothesis.
} 
analyses of government debt and interest rates do not account for foreign sector lending and purchases of U.S. Treasury securities.

Finally, the interest rate is also affected by other general macroeconomic factors besides capital that influence output $(Y)$; in the simple model here, that includes labor and multifactor productivity. Thus there is usually some accounting for general macroeconomic factors that can affect the performance of the economy in empirical analyses of the effect of government debt on interest rates.

Certain assumptions_-Ricardian equivalence or perfectly open international capital markets in which foreign saving flows in to finance domestic government borrowing - provide one benchmark for the potential effect of government debt on the interest rate. In these scenarios, government debt does not crowd out capital (i.e., $\partial K / \partial D$ $=0$ ) and, thus, has no effect on the interest rate. For the alternative crowding-out hypothesis (i.e., $-1 \leq \partial K / \partial D<0)$, the production-function framework presented above can provide a range of plausible calculations of the potential increase in interest rates from an increase in the government debt.

By taking logs of the interest rate equation above, differentiating, and noting that $d \ln x$ is approximately equal to the percentage change $(\% \Delta)$ in $x$ yields:

$$
\% \Delta r=\% \Delta Y-\% \Delta K=(\alpha-1)(\% \Delta K)+(1-\alpha) \% \Delta L
$$

Because labor input is typically held constant (i.e., $\% \Delta L=0$ ) in the debt-crowd-out experiment,

$$
\% \Delta r=(\alpha-1)(\% \Delta K)
$$


For the purpose of calculating a benchmark, we assume that the capital share of output is $\alpha=1 / 3$, which is approximately equal to its historical value in the United States. National accounts data suggests that the marginal product of capital is about 10 percent. The value of U.S. private fixed assets (less consumer durables) is about $\$ 31$ trillion. $^{4}$ Thus an increase in government debt of one percent of GDP—equal to about $\$ 110$ billion - would reduce the capital stock by 0.36 percent, assuming that there is no offset to the increase in federal debt from increased domestic saving or inflows of foreign saving (i.e., $\partial K / \partial D=-1$ ). Multiplying this percentage decline by -0.67 (which is equal to $\alpha-1$, where $\alpha=0.33$ ) implies an increase in the marginal product of capital of 0.24 percent. The resulting increase in interest rates is 2.4 basis points, as shown in the first column of Table 1. Similarly, a government surplus of one percent of GDP would be expected to decrease interest rates 2.4 basis points.

If the increase in federal debt were larger-five percent of GDP — then interest rates are calculated to rise by 11.8 basis points, as the second row of the first column in Table 1 shows. This effect could be the result of an increase in federal debt in a single year, or the result of a persistent increase in federal debt (i.e, a persistent deficit) of one percent of GDP per year over five years. An increase in the federal debt of ten percent of GDP - again, the result of a one-time increase or the consequence of a persistent increase

\footnotetext{
${ }^{4}$ We calculate the private capital stock using data in the Federal Reserve's Flow of Funds Accounts on the fixed assets of the household, business, farm (excluding farm land, which is not included in the Accounts), and non-profit sectors of the economy. This measure does not include stocks of consumer durables or business inventories. Moreover, this measure understates the size of the total capital stock in the United States that could potentially be affected by federal government debt since it does not include the capital of state and local governments, and thus somewhat overstates the potential percentage change in interest rates from federal government debt crowding out capital formation in other sectors of the economy.
} 
in federal debt of 1 percent of GDP per year over ten years-would increase interest rates by 23.7 basis points. ${ }^{5}$

Currently, total federal debt held by the public is about $\$ 4$ trillion, or 12.9 percent of the $\$ 31$ trillion private capital stock. Holding other factors constant, eliminating the federal debt (measured in this way) entirely, and assuming it would increase the private capital stock on a one-for-one basis, implies a decrease in interest rates of 86 basis points, as shown in the fourth row of the first column.

The calculations in the first column of Table 1 assume no offset from increased private saving or capital inflows from abroad, which is not consistent with the U.S. economic experience. As shown in the second column, if, for example, 20 percent of the increase in government debt is offset by these factors (i.e., $\partial K / \partial D=-0.8$ ) then a $\$ 110$ billion (one percent of GDP) increase in federal government debt would reduce the U.S. capital stock by $\$ 88$ billion, or about 0.28 percent. This implies an increase in the marginal product of capital of 0.19 percent, so the resulting increase in interest rates is about 1.9 basis points. An increase in federal debt of five percent of GDP—or a $\$ 550$ billion increase in government debt—would increase the interest rate by 9.5 basis points. Alternatively, totally eliminating the federal debt is calculated to reduce interest rates by about 69 basis points. Assuming a larger, but plausible, offset to increases in federal debt

\footnotetext{
${ }^{5}$ Expectations of future government borrowing are not part of the simple framework presented here. But it is probably a reasonable benchmark to assume that the expected crowding-out effect on current interest rates from expected future federal borrowing is similar in magnitude to the calculations presented here; i.e., if borrowing is expected to be higher by one percent of GDP in each of the next ten years then the current real interest rate may be expected to be about 24 basis points higher. However, Cohen and Follette (2003) have shown that budget deficit forecasts beyond one year are typically very poor, primarily owing to the difficulty in forecasting federal tax receipts. See Congressional Budget Office (2004) also for a discussion about the difficulty of forecasting federal budget deficits.
} 
from domestic and/or foreign saving of 40 percent (i.e., $\partial K / \partial D=-0.6)^{6}$, suggests that even an increase in federal debt equal to ten percent of GDP would only increase interest rates by 14 basis points. Under this scenario, eliminating the federal debt would lower interest rates a little over 50 basis points.

These calculations provide a reasonable benchmark for evaluating the traditional crowding-out effect on interest rates of an exogenous increase in government debt, holding other factors constant. Given the size of deficits and surpluses seen in the United States, these effects are more subdued than one might think given some of the commentary on federal deficits and interests rates. However, because other factors that influence interest rates are not constant, changes in government debt are influenced by both exogenous and endogenous factors, and the likely interest rate effects of changes in federal government debt consistent with historical U.S. experience may be in the range of single-digit basis points, this poses a particular burden on empirical analysis to estimate these effects with less-than-perfect data and econometric techniques.

\section{Empirical Evidence: Is There a Clear Answer?}

Because economic theory is not conclusive in determining whether federal government debt raises interest rates, and if it does, by how much, then this issue must ultimately be addressed by empirical analysis. However, model-based calculations of the potential effects of government debt on interest rates are instructive and provide some benchmarks to help assess empirical estimates of this relationship. Before turning to econometric analysis of the possible effects of federal government debt on interest rates

\footnotetext{
${ }^{6}$ This is a measure of the degree of offset to federal government borrowing that is consistent with a discussion in Council of Economic Advisers (1994), for example.
} 
in the United States, we first examine some basic empirical facts about government debt, interest rates, and other related factors in the U.S. economy. These facts illustrate some of the difficulties posed for econometric analysis.

\section{A. Some Basic Facts}

Over the past half-century U.S. federal government debt held by the public as a percent of GDP has fluctuated from a high of about 60 percent of GDP to a low of around 25 percent of GDP in the mid-1970s, as shown in Figure $1{ }^{7}$ While federal debt climbed during the 1980s and early 1990s to almost 50 percent of GDP, it declined thereafter and still remains below 40 percent of GDP despite its recent upturn.

Federal borrowing, or the yearly change in federal debt, as a percent of GDP has averaged about two percent over the past fifty years, and has fluctuated from peaks around five percent of GDP to the retirement of debt equal to about three percent of GDP in 2000, as shown in Figure $2 .{ }^{8}$ Not surprisingly, federal borrowing tended to rise shortly after the recession episodes in 1974-75, 1980-81, 1990-91, and 2001.

One of the primary concerns about federal debt is its potential to crowd out the formation of capital in the economy. Figure 3 shows federal government debt as a percentage of the U.S. private capital stock. ${ }^{9}$ Federal government debt is currently equal

\footnotetext{
${ }^{7}$ Data on federal government debt held by the public are from the Federal Reserve's Flow of Fund Accounts, and includes federal debt held by the Federal Reserve. This measure of federal government debt does not, of course, include the implicit unfunded liabilities associated with the Social Security and Medicare programs. Data for GDP are from the National Income and Product Accounts produced by the Bureau of Economic Analysis.

8 "Federal borrowing" here is the net issuance of new federal debt, as measured by the Federal Reserve's Flow of Funds Accounts, and thus is not exactly equal to the federal "unified federal budget deficit" though it is closely correlated with it. However, it is a measure that captures better the potential effects of federal borrowing in credit markets.

${ }^{9}$ This measure of the U.S. private capital stock is constructed with data from the Federal Reserve's Flow of Fund Accounts, as we described in footnote 4.
} 
to about 13 percent of the private capital stock, which provides an upper bound on the amount of capital that federal debt could have directly crowded out.

The federal government is not the only borrower in U.S. credit markets, and indeed it is not the largest. Figure 4 shows that federal government debt as a share of total U.S. domestic (nonfinancial) debt has declined significantly since 1953, and it currently is less than 20 percent of total debt. ${ }^{10}$ Figure 5 shows annual federal borrowing relative to total domestic U.S. borrowing. Federal government borrowing currently claims about one-fifth of the total funds loaned in U.S. credit markets. As global capital markets have become more integrated over time, the relevant size of the loanable funds market in which federal government debt interacts is much larger than the size of just the U.S. credit market, and thus these two figures overstate the relative size of federal debt and borrowing in the pool of available loanable funds. We return to this point below.

The debt incurred by the household, business, and state and local government sectors, consistently has been larger than that incurred by the federal government over the past fifty years; it has also grown at a faster rate. Figure 6 shows U.S. domestic nonfederal (nonfinancial) debt as a percentage of GDP. Currently standing at approximately 160 percent of GDP, domestic nonfederal debt is about four times as large as federal government debt. Figure 7 presents annual nonfederal borrowing as a percentage of GDP; such borrowing has consistently been greater than federal borrowing over the past fifty years, except during the credit crunch of the early 1990s.

Foreign saving is an ever more important source of funds to U.S. credit markets, one which could also potentially influence the effect of federal government debt on

\footnotetext{
${ }^{10}$ We constructed data for U.S. domestic (nonfinancial) debt and borrowing used in Figures 4 through 7 from the Federal Reserve's Flow of Funds Accounts.
} 
interest rates. Indeed, foreign funds increasingly have been used to purchase U.S. federal government debt. As shown in Figure 8, while foreign holdings of U.S. Treasury securities where less than five percent of total outstanding federal debt just over 30 years ago, foreign purchases of Treasury securities have increased dramatically since then, and foreigners currently hold a little more than one-third of total federal debt. ${ }^{11}$ Note that the recent surge in foreign holdings of U.S. Treasury securities is not unprecedented, as both the early 1970s and the mid-1990s were periods when foreigners significantly increased their holdings of Treasury instruments.

Domestic private savers and foreign savers are not the only sectors that hold debt issued to the public by the federal government. As the U.S. monetary authority, the Federal Reserve also holds Treasury securities, using them in conducting monetary policy. The Federal Reserve currently holds about 15 percent of outstanding Treasury securities, up from around ten percent about a decade ago, as Figure 9 shows. In a growing economy, the Federal Reserve must consistently acquire some Treasury securities in open-market operations to expand the money supply and prevent deflation, as we noted in the previous section. Treasury debt that is purchased by the Federal Reserve in order to increase the money supply may not have the same effect of crowding out private capital formation as federal debt purchased by the private sector.

Financing decisions of the federal government along with those of private sector borrowers, state and local government borrowers, domestic and foreign savers, and the Federal Reserve all interact in the U.S. and international credit market to influence interest rates on U.S. Treasury debt and other debt. To get a sense of what effect U.S.

\footnotetext{
${ }^{11}$ Data on U.S. Treasury security holdings shown in Figures 9 and 10 are from the Federal Reserve's Flow of Funds Accounts.
} 
federal government debt has had on interest rates, it is instructive to look at the historical evolution in federal debt (relative to GDP) compared to interest rates over the past fifty years. Figure 10 shows U.S. federal government debt held by the public as a percentage of GDP and a measure of the real interest rate on ten-year Treasury securities. ${ }^{12}$ While federal debt relative to GDP has varied substantially, the real interest rate has been less variable, and is currently equal to its average value over the past fifty years of about three percent. Indeed, the simple correlation between the stock of federal debt and this measure of the real interest rate over the entire period shown is only 0.15 . Over the twenty-year period from the early 1950s to the early 1970s—-when federal debt decreased by 50 percent relative to the size of the economy - the real interest rate remained relatively constant. The real interest rate did rise in the early 1980s, coincident with an increase in federal debt, but the real interest rate then declined and remained quite steady even as federal debt continued to grow in the 1980s and early 1990s, and then fell in the late 1990s.

Figure 11 shows annual federal government borrowing as a percentage of GDP relative to the real rate on ten-year Treasury securities. Here the correlation between federal government borrowing and the real interest rate is 0.39 , higher than between federal government debt and the real interest rate, but still modest. As we noted earlier, a simple economic model of crowding-out implies that federal government borrowing, which is equal to the change in federal government debt, is related to the change in the real interest rate rather than the level of the real interest rate, as shown in Figure 11. Figure 12 plots federal government borrowing (as a percentage of GDP) relative to the

\footnotetext{
${ }^{12}$ Data on nominal ten-year Treasury yields are from the Federal Reserve. The real interest rate is computed by subtracting the average expected inflation rate for the CPI from the Livingston Survey compiled by the Federal Reserve Bank in Philadelphia.
} 
change in the real ten-year Treasury rate. The correlation between federal borrowing and the change in the real interest rate is 0.06 , much smaller than the correlation between federal borrowing and the level of the real interest rate.

In addition to the concern that federal government debt might crowd out private capital formation by causing real interest rates to rise, federal government debt may also pose the temptation to monetize the debt, causing inflation. The presentation in Figure 13 of data for federal government debt (as a percentage of GDP) and both the expected inflation rate and the inflation rate shows that this concern has not been a problem in the United States over the past fifty years. ${ }^{13}$ The correlation between federal government debt and the actual inflation rate is -0.71 over this period (and is similar for the expected inflation rate); inflation peaked when the federal debt relative to GDP was at its lowest points and declined as federal debt grew in the 1980s.

Returning to the potential effects of government debt on real interest rates, it is also useful to examine the difference in real interest rates between the United States and other major industrial economies. If international capital markets were not well integrated, then real interest rates might vary according to differences in government debt and borrowing patterns. Alternatively, if credit markets were integrated in the global economy, then real interest rates might be expected to be more similar across these different economies. Figure 14 presents real interest rates on ten-year government securities for the United States, Canada, France, Germany, Italy, Japan, and the United

\footnotetext{
${ }^{13}$ The expected inflation rate is the same measure from the Livingston Survey used to construct the real interest rate in the previous charts. The actual rate of inflation is measured by the growth rate in the price index for personal consumption expenditures in the National Income and Product Accounts.
} 
Kingdom since $1990 .{ }^{14}$ Over this period real interest rates have generally declined, and there currently is much less dispersion in these real interest rates than there was in the early 1990s. Italy has the lowest real interest rate—just below two percent—while Germany has the highest at just under four percent. However, the current government financial positions of these countries are quite different. While Japan currently has a stock of government debt of more than 70 percent of GDP, and an annual budget deficit of about seven percent of its GDP, its real interest rate is virtually the same as the United States and France, which both have stocks of government debt and flow deficits (both relative to GDP) about half the size of those in Japan. Italy, currently with the lowest real interest rate, has a ratio of government debt to GDP of more than 90 percent, the highest in this group of economies. The United Kingdom currently has a deficit to GDP ratio of 1.5 percent, and Canada has a government surplus of almost one percent, but real interest rates in those countries are somewhat higher than in the United States. The similarity of real interest rates across these countries despite having very different government borrowing needs suggests that global credit markets are fairly integrated, so that the pool of loanable funds that any government may draw from substantially exceeds funds in the domestic credit market alone.

There are several basic points that summarize our assessment of these data on U.S. federal government debt and interest rates. First, the federal government is not the largest borrower in the U.S. domestic credit market, and the stock of outstanding federal debt has generally remained under 25 percent of total U.S. domestic debt for the past 30

\footnotetext{
${ }^{14}$ These measures of the real interest rate are constructed using data from the Organization for Economic Cooperation and Development (OECD) for nominal ten-year government bond yields and the actual rate of growth in the price index for personal consumption expenditures in each country's national income accounts. To our knowledge, measures of expected inflation for each country are not readily available.
} 
years. Second, there is strong evidence that global credit markets have become increasingly integrated, so the relative role of U.S. federal government borrowing in the relevant international market for loanable funds is even smaller than in the domestic credit market. Third, the simple bivariate correlation between federal government debt and real interest rates in the United States has been quite weak over the past fifty years, so a strong positive relationship between federal government debt and real interest rates is not obvious. Of course, more rigorous econometric analysis of this relationship is necessary before a more definitive conclusion can be drawn.

\section{B. Review of Previous Studies}

Several different surveys over the past twenty years have evaluated the empirical literature on the relationship between federal government debt and interest rates: Barth, Iden, and Russek (1984), Bernheim (1987, 1989), Barro (1989), Barth, Iden, Russek, and Wohar (1991), Seater (1993), Elmendorf and Mankiw (1999), and Gale and Orszag (2002, 2003), for example. Despite the volume of work, no universal consensus has emerged. For example, Barth, Iden, Russek, and Wohar (1991), referring also to their earlier review, write: "There was not then and there is not now a clear consensus on whether there is a statistically and economically significant relationship between government deficits and interest rates... Since the available evidence on the effects of deficits is mixed, one cannot say with complete confidence that budget deficits raise interest rates and reduce saving and capital formation. But, equally important, one cannot say that they do not have these effects." 
In their surveys of studies of Ricardian equivalence, Bernheim $(1987,1989)$ and Seater (1993) enumerate problems with tests of this hypothesis performed by examining the relationship between federal government debt and deficits with interest rates. Bernheim (1989) concludes that: “... it is easy to cite a large number of studies that support any conceivable position." However, in the end, Seater generally finds more overall support for the Ricardian equivalence hypothesis, which implies that federal government debt has no effect on interest rates, than does Bernheim, who argues that the Ricardian equivalence hypothesis should be rejected, which would make a positive relationship between federal government debt and interest rates more likely. Barro (1989) takes a similar position as Seater, concluding: "Overall, the empirical results on interest rates support the Ricardian view. Given these findings, it is remarkable that most macroeconomists remain confident that budget deficits raise interest rates."

In discussing empirical research on federal government debt and interest rates, Elmendorf and Mankiw (1999) state that: “...it is worth noting that this literature has typically supported the Ricardian view that budget deficits have no effect on interest rates." However, they go on to evaluate this evidence, writing: "Our view is that this literature, like the literature regarding the effect of fiscal policy on consumption, is ultimately not very informative. Examined carefully, the results are simply too hard to swallow...". Gale and Orszag (2002) in their survey of the economic effects of federal government debt also acknowledge that: “...the evidence from the literature as a whole is mixed", but go on to conclude: "Closer examination of the literature, however, suggests the findings may not be as ambiguous as they initially appear. Indeed, studies that (properly) incorporate deficit expectations in addition to current deficits tend to find 
economically and statistically significant connections between anticipated deficits and current long-term interest rates."

Thus, while surveys of the empirical literature on federal government debt and interest rates note the wide range of results reported in different studies, interpretations and assessments of these mixed empirical results still differ. While we do not evaluate every empirical paper that has been written on the relationship between federal government debt and interest rates, we will offer an assessment of the existing literature, focusing primarily on more recent papers.

Many studies analyzing the effects of U.S. federal government debt or deficits on U.S. interest rates do not incorporate the potential effects of the fact that international financial markets are increasingly integrated. To account for this, Barro and Sala-iMartin (1990) and Barro (1991) provide estimates of the effects economic, fiscal, and monetary policy variables on expected real world interest rates across ten major developed economies, including the United States. They use a structural approach where the world interest rate is determined by investment demand and desired saving. While, they conclude that current government debt or deficits do not play an important role in the determination of real expected interest rates in these countries, their empirical analysis does not use expected future government deficits or debt.

Cohen and Garnier (1991) use forecasts of federal deficits for the United States provided by the Office of Management and Budget (OMB), and in additional analysis also investigate the effects of forecasts of general government deficits made by the Organization for Economic Cooperation and Development (OECD) on interest rates across the G7 countries. Their analysis yields mixed results. For the United States, they 
generally do not find significant effects of the current deficit or expected deficits on interest rates, although they do find a significant statistical relationship between OMB deficit forecast revisions and interest rates in the United States. Their estimates imply that an upward revision in OMB's federal deficit forecast of one percentage point of GDP could increase real interest rates by about 80 to100 basis points. However, the theoretical calculations that we presented earlier raise the question of whether this result is economically plausible. In their analysis of the G7 countries, they find no evidence of a positive and significant relationship between home country current debt or deficits and current interest rates, similar to Barro and Sala-i-Martin (1990) and Barro (1991), and find that one-year-ahead forecasts of home-country government deficits by the OECD tend to have a significant negative effect on nominal short-term interest rates, in contrast to the prediction of the government deficit crowding-out hypothesis. However, one-yearahead forecasts of other-country government deficits by the OECD tend to have a significant effect on home-country nominal short-term interest rates in the direction consistent with the government deficit crowding-out hypothesis, and also imply that credit markets across these countries are integrated.

Cebula and Koch (1989) explore the effect of the current U.S. federal government deficit, split into its cyclical and structural components, on both ten-year Treasury yields and corporate bond yields, while also controlling for foreign capital inflows. Their results imply that positive foreign capital inflows significantly lower both Treasury and corporate rates, consistent with integrated global credit markets, and significantly reduce the estimated effect of structural government deficits on interest rates. They find a statistically insignificant effect of the structural federal government deficit on Treasury 
yields, while reporting a statistically significant effect of the structural federal government deficit on corporate bond yields, implying that the structural federal government deficit affects the yield spread between corporate and Treasury rates. It is not obvious why structural federal government deficits should affect the corporate to Treasury yield spread. In contrast, Laubach (2003) reports that, based on regression analysis, he finds no evidence that yield spreads between corporate bonds and Treasuries, adjusted for cyclical variation, are systematically related to projected deficit-to-GDP ratios. Thus the fact that Cebula and Koch are using current federal deficits in their analysis instead of expected federal deficits may be contributing to their result. ${ }^{15}$

Elmendorf (1993) analyzes the effect of expected federal government deficits on Treasury yields using a private-sector forecast of the federal government deficit from Data Resources, Inc. (DRI), instead of federal government deficit projections made by OMB or the Congressional Budget Office (CBO). Presumably, the DRI deficit forecast incorporates expectations of fiscal policy changes that are not part of $\mathrm{CBO}$ and $\mathrm{OMB}$ projections, and thus may be a more accurate reflection of financial market participants' expectations of future federal government deficits. Regression results show that the DRI forecasts of federal government deficits have significant and large (and statistically significant) positive effects on medium-term (three- or five-year) Treasury yields—an increase in the expected deficit of one percent of GDP is estimated to increase mediumterm Treasury rates by more than 40 basis points—-but have a smaller and statistically

\footnotetext{
${ }^{15}$ In a subsequent paper by Cebula and Koch (1994), again investigating the effects of current federal government deficits and capital inflows on corporate yields, they do not separate the deficit into its structural and cyclical components, and do not report results of the effects of deficits and capital inflows on Treasury yields. Given the results of their 1989 analysis, these are significant omissions, so it is not clear how to interpret their findings of a positive effect of government deficits on corporate yields in their 1994 paper.
} 
insignificant effect on a long-term (20-year) Treasury rate. If federal government borrowing is crowding out private capital formation then one would expect to find a larger impact on long-term interest rates than on shorter-term interest rates.

Kitchen (2002) examines the effects of the CBO's current 'standardized' federal government deficit measure — which adjusts the actual deficit for business cycle effects and other (usually) one-time budget effects—on the spread between the three-month Treasury yield and longer-term Treasury rates, rather than the level of Treasury rates. In a parsimonious specification controlling only for inflation and the difference between actual GDP and CBO's measure of potential GDP, he estimates that a one percent increase in the current standardized federal government deficit (relative to GDP) increases the spread between the ten-year Treasury rate and the three-month Treasury rate by 42 basis points. This estimate is much larger than the benchmark calculations from our simple economic framework presented above. Moreover, Kitchen uses a regression specification - effectively regressing the level of the interest rate on the federal deficitthat is not implied by the model. Also, because the estimates are based on current measures of interest rates and the federal deficit, it is not obvious whether the influence of other economic factors that might affect the interest rate, but are not included in his parsimonious regression specification, is affecting the estimate of the effect of federal deficits.

Laubach (2003) estimates the effect of five-year-ahead projections by CBO of federal government debt or deficits on the five-year-ahead real ten-year Treasury yield. The purpose for using five-year-ahead interest rates and debt or deficit projections is to try to omit any effects of current economic conditions from measuring the effects of 
federal government deficits on the interest rate. He finds that a one-percentage-point (relative to GDP) increase in the measure of the expected federal government deficit increases the forward-looking ten-year Treasury rate by 28 basis points. However, when Laubach estimates an econometric specification that uses expected federal government debt instead of the deficit, which, in contrast to using a deficit measure, is a specification consistent with a standard economic model of crowding-out, he estimates that a onepercentage-point increase in the expected debt-GDP ratio increases the forward-looking ten-year Treasury rate by only five basis points — an estimate close to the benchmark calculations we presented previously. Thus these results illustrate that whether an interest rate measure is regressed on the federal government deficit or on the federal government debt can yield markedly different implications for the magnitude of the associated interest rate effect.

Laubach suggests that the difference in these results can be reconciled by the fact that federal budget deficits tend to be serially correlated in historical U.S. data, and thus financial market participants may expect an increase in the federal government deficit to be persistent, and thus there is a larger increase in interest rates. ${ }^{16}$ However, federal government debt is also serially correlated in U.S. data. This is not surprising because federal government debt $\left(D E B T_{t}\right)$ at the end of time period $t$ is the sum of the federal budget deficit $\left(D_{E F I C I T_{t}}\right)$ during time period $t$ and federal government debt at the end of the prior period, $t-1$ :

$D E B T_{t}=$ DEFICIT $_{t}+D E B T_{t-1}$.

\footnotetext{
${ }^{16}$ In related research, Auerbach (2003) and Bohn (1998) note that U.S. fiscal policy appears responsive to fiscal conditions so that spending is reduced and/or taxes are raised when federal debt and deficits increase.
} 
If financial market participants expect an increase in federal government deficits to be persistent then they should also expect increases in federal government debt to be persistent, so it is not clear that this explanation reconciles the difference in the estimated interest rate effects when using federal deficits instead of federal debt. Indeed, current (end-of-period) debt contains information not only about the current deficit but also captures all information about previous government borrowing, and thus is a better measure to evaluate the effect of government borrowing on the level of the interest rate, as suggested in our theoretical discussion above. The change in government debt, or the deficit, would be expected to affect the change in the real interest rate, not necessarily the level of the interest rate, but that is not the econometric specification used by Laubach. We return to this point in our empirical work below.

Miller and Russek (1996) show that different econometric approaches can yield different conclusions about the effect of federal government deficits on interest rates. While their conventional estimates of reduced-form specifications indicate that increases in the current real per capita deficit increases current nominal Treasury rates (although it is difficult to interpret the magnitude of this effect from their reported regression results), using vector autoregression (VAR) methods yields mixed results about this relationship. ${ }^{17}$

Evans and Marshall (2002) use a VAR framework to investigate the macroeconomic determinants of the variability in the nominal Treasury yield curve. They find that general macroeconomic shocks account for most the variability in nominal

\footnotetext{
${ }^{17}$ In related analysis, Russek and Miller (1991) find use Granger-causality tests to assess the relationship between federal government deficits and long-term Treasury rates. They find bidirectional causality between current real per capita federal government deficits (or current real per capita federal debt) and long-term interest rates. However, again it is difficult to interpret the magnitude of the effect on interest rates from their results.
} 
Treasury yields, with fiscal policy shocks generally having mixed effects. Their measure of fiscal deficit shocks — derived from Blanchard and Perotti (2000)—does not significantly explain nominal Treasury yield variability. However, they do find that the measure of military buildup shocks suggested by Ramey and Shapiro (1997) tends to increase nominal Treasury rates.

Another approach to looking at the effects of federal government deficits on interest rates has been to focus on media-reported budget news. If news concerning federal government deficits occasionally leads to significant movements in bond market prices then standard time-series techniques may have little power to identify these occasional, possibly nonlinear, events. Previous economic research that has analyzed the effects of news announcements about federal government deficits on interest rates (Wachtel and Young, 1987; Thorbecke, 1993; Quigley and Porter-Hudak, 1994; Kitchen, 1996), have generally found only small or transitory effects. Elmendorf(1996) found that higher expected federal deficits and government spending tended to raise interest rates, but his methodology does not provide evidence of the magnitude of the effect.

Calomiris, Engen, Hassett, and Hubbard (2003) add to this analysis of the effects of federal budget news on interest rates in two ways. First, they estimated the extent to which monthly deviations of private-sector consensus forecasts of the federal government budget balance from actual monthly Treasury budget balance reports, along with deviations in consensus forecasts and actual reports on other macroeconomic variables, predict movements in interest rates. They found that stronger than expected reports on a number of macroeconomic factors (such as the employment situation, industrial production, and retail sales, for example) tended to increase interest rates, but actual 
deviations from expected monthly federal government budget deficits had no statistically significant effect on interest rates. Second, they collected historical data on large daily movements in interest rates, and catalogue the economic news that occurred on these days. Typically, the days with large interest rate movements are associated with general economic news, rather than with federal budget news, and the movement in interest rates is consistent with what economic theory would suggest; that is, news that suggests more robust economic growth is associated with increases in interest rates. Both of these approaches yielded little evidence that unexpected news about the federal budget situation had significant effects on interest rates.

Evaluating effects of government debt on interest rates is difficult given the lack of consensus on the appropriate underlying economic model of how federal debt or deficits and interest rates should interact. Moreover, variable definitions and other features of the data and econometric methodology vary across these studies, making it difficult to make comparisons. As with most of the earlier reviews of the economic literature on federal debt, deficits, and interest rates, our view is that the existing evidence is quite mixed. Some studies find positive effects of federal deficits on interest rates and others do not. Moreover, even among the studies that do find a positive effect of deficits on interest rates, the magnitude of the effect on interest rates is still uncertain. However, looking systematically at the influence of different econometric specifications, different measures of federal government debt or deficits, different measures of the interest rate, and different of econometric methodologies the estimated effect of federal government debt on interest rates hopefully will provide some insight into this issue. 


\section{Empirical Analysis of Federal Debt and Interest Rates}

We now provide some new empirical evidence on the potential effects of federal government debt on interest rates. Consistent with most prior analysis, we initially examine this relationship by estimating a reduced-form equation:

$$
i_{t}=\beta_{0}+\beta_{1} d_{t}+\Gamma Z+\varepsilon_{t},
$$

where $i_{t}$ is a measure of the interest rate (in time period $t$ ), $d_{t}$ is a measure of federal government debt, and $Z$ is a vector of other relevant variables that may influence interest rates. The effect of federal government debt on the interest rate is described by the estimate of the coefficient, $\beta_{1}$.

The specification of the interest rate variable, $i$, and the federal government debt variable, $d$, in the reduced-form equation can take different forms. As we noted earlier, the hypothesis that federal government debt might crowd out private capital formation, and thus raise long-term real interest rates, is typically based on a simple economic model as we presented above. ${ }^{18}$ This model implies that:

(1) the level of the real interest rate, $i$, is related to the level, or stock, of federal government debt, $d$, or

(2) the change in the real interest rate, $\Delta i$, is related to the change in federal government debt, $\Delta d$, which is equal to federal government borrowing, or the deficit. We estimate this reduced-form equation using both of these specifications for $i$ and $d$. Although not consistent with the specifications for $i$ and $d$ implied by an economic model

\footnotetext{
${ }^{18} \mathrm{We}$ focus on the effect of federal government debt on a measure of the real, long-term interest rate because that is the measure of the interest rate most likely to be affected by federal government debt if it is crowded out private capital formation. Accordingly, we use a measure of the ten-year Treasury yield, adjusted for expected inflation, for our analysis.
} 
of crowding-out, we also estimate this reduced-form equation using a third specification in which:

(3) the level of the real interest rate, $i$, is regressed on federal government borrowing (or the deficit), $\Delta d$.

A number of prior studies have used this third specification, and it is informative to compare the results from using this specification with those that employ the previous two specifications, even though it is not consistent with a simple crowding-out model.

Economic theory suggests that it is the total stock of government debt that is the most relevant for explaining the level of the interest rate, not just the one-period change in government debt.

Another important issue for specifying $i$ and $d$ is whether these are forwardlooking, or expected, measures of real interest rates and federal government debt, or whether they are current measures of these variables. Previous studies have varied in whether forward-looking or current measures of interest rates and federal government debt were used in their analysis. To compare how these different specifications for $i$ and $d$ affect estimates of the relationship between these two variables, we provide estimates for three different types of specifications. In particular:

(1) we estimate the effect of an expected, or projected, measure of federal government debt on a forward-looking measure of the real interest rate;

(2) we estimate the effect of an expected, or projected, measure of federal government debt on a current measure of the real interest rate; and

(3) we estimate the effect of a current measure of federal government debt on a current measure of the real interest rate. 
A number of other economic variables should be included in the vector $Z$, as they also presumably influence the determination of the real interest, $i$, and excluding them could bias the estimate of the coefficient $\beta_{1}$. As we noted in the earlier section discussing the potential theoretical effect of federal government debt on interest rates, it is important to account for general macroeconomic factors that can affect the performance of the economy. Accordingly, in the vector $Z$, we include the growth rate in real GDP, which is a variable usually included in these types of regressions. ${ }^{19}$ Moreover, the analysis by Barro and Sala-i-Martin (1991) and Barro (1991) finds that real oil prices also are an important exogenous macroeconomic variable that can affect real interest rates, so we include a measure of real oil prices in the vector $Z .^{20}$

Laubach (2003) observes that in a Ramsey model of economic growth, where the preferences of a representative household are incorporated with a production function similar to the one we presented in section II above, the real interest rate, $r$, is determined by:

$$
r=\sigma g+\theta
$$

where $\sigma$ is the coefficient of relative risk aversion for the representative household in the model, $g$ is the growth rate of technology, and $\theta$ is the rate of time preference for the representative household. He estimates that a measure of the equity premium-used as a proxy for risk aversion - is an important factor affecting real interest rates, so we include

\footnotetext{
${ }^{19}$ Data for the growth rate of real GDP are available in the National Income and Product Accounts produced by the Bureau of Economic Analysis.

${ }^{20}$ Data for inflation-adjusted domestic crude oil prices in the United States are obtained from the Department of Energy. Barro and Sala-i-Martin (1990) and Barro (1991) find that an increase in the real price of oil tends to increase the real interest rate, presumably because the resulting decline in investment demand is dominated by the fall in desired saving.
} 
it in the vector $Z .^{21}$ If relative risk aversion declines, then households may be more willing to purchase equities than debt instruments, thereby leading to a rise in the interest rate.

Fiscal policies other than federal government debt may also affect real interest rates. Ramey and Shapiro (1998) and Evans and Marshall (2002) find that exogenous defense spending shocks — measured by Ramey and Shapiro as a dummy variable denoting the time period in which a significant military buildup begins - tend to increase interest rates. ${ }^{22}$ This effect is consistent with the theoretical implication of an exogenous increase in government consumption in a neoclassical model even if the Ricardian equivalence hypothesis is operative. ${ }^{23}$ Therefore we include a variable to capture exogenous defense spending shocks in the vector $Z .^{24}$

While conducting monetary policy the Federal Reserve regularly purchases U.S. Treasury securities as the economy grows, which may reduce the impact of federal government debt on the real interest rate. Thus we include a variable measuring the purchase of U.S. Treasury securities by the Federal Reserve, relative to GDP, in our specification of the regression equation. ${ }^{25}$

\footnotetext{
${ }^{21}$ As in Laubach (2003), we calculate the equity premium as dividend income from the National Income and Product Accounts, as a percentage of the market value of corporate equities held by households in the Federal Reserve's Flow of Fund Accounts, plus the trend growth rate in real GDP, minus the real ten-year Treasury yield.

${ }^{22}$ See Cohen and Follette (2003) and Eichenbaum and Fisher (2004) for more discussion about exogenous defense spending shocks.

${ }^{23}$ See, for example, Bernheim (1987), Barro (1989), and Seater (1993). Baxter and King (1993) show, however, that in a neoclassical model that the interest rate may only increase in the short run but be unchanged in the long run.

${ }^{24}$ The time periods denoted in this dummy variable as significant military buildups includes the beginning of the Vietnam war buildup in 1965, the Carter-Reagan military buildup beginning in 1980, as in Ramey and Shapiro (1998), and also adds the beginning of the military buildup for the war in Afghanistan and Iraq in 2002, as in Eichenbaum and Fisher (2004).

${ }^{25}$ This variable is constructed using data on Federal Reserve purchases of U.S. Treasury securities from the Federal Reserve's Flow of Funds Accounts expressed as a ratio to GDP from the National Income and Product Accounts.
} 
To summarize, in vector $Z$ of the regression equation, we include the following variables:

(1) the rate of growth in real GDP,

(2) the real domestic crude oil price,

(3) a measure of the equity premium (as a proxy for risk aversion),

(4) a dummy variable for military buildups,

(5) Federal Reserve purchases of U.S. Treasury securities.

We now turn to our empirical results. ${ }^{26}$

\section{C1. Forward-looking Interest Rates and Federal Government Debt}

The only previous study of which we are aware that analyzes the effect of forward-looking projections of federal government debt on a forward-looking measure of the real interest rate is Laubach (2003). The purpose for using these forward-looking measures is to attempt to omit any effects of current economic conditions and policies from the empirical estimate of the effect of federal government debt on interest rates.

Laubach constructs data from 1976 through 2003 on nominal ten-year Treasury rates expected to prevail five years ahead, and then subtracts a series of inflation expectations taken from the Federal Reserve's econometric model of the United States. These data on real five-year-ahead ten-year Treasury yields are calculated to coincide with the CBO's five-year-ahead projections of federal government debt and deficits,

\footnotetext{
${ }^{26} \mathrm{We}$ do not include additional variables to capture other demands on loanable funds- - such as private sector debt — and sources of loanable funds — such as domestic and foreign saving — because of significant potential endogenity problems.
} 
relative to GDP, released in its annual Economic and Budget Outlook. ${ }^{27}$ In this section, we use these measures of the forward-looking real interest rate and forward-looking federal government debt in our analysis. We also use the CBO's five-year ahead projection of real GDP growth rate. The other variables correspond to the time period just preceding the release of the CBO's annual report.

In the first column of Table 2, we report coefficient estimates for regressions of the real five-year-ahead ten-year Treasury yield on the five-year projection of federal government debt along with the other variables. The results imply that a one-percentagepoint (relative to GDP) increase in CBO's five-year-ahead projection of federal government debt increases the real five-year-ahead ten-year Treasury yield by a little less than three basis points, and the estimate is statistically significantly different from zero. ${ }^{28}$ This estimate is also consistent with the theoretical calculations presented in Table 1. The estimated coefficients on all of the other variables have the expected sign and are statistically significant from zero, except for the insignificant coefficient estimate on the projected real GDP growth rate. $^{29}$

\footnotetext{
${ }^{27}$ We thank Thomas Laubach for making these data on forward-looking real interest rates available to us; see Laubach (2003) for more details on the calculation of these data. The data do not go back earlier than 1976 because the CBO has been in existence only since the mid-1970s.

${ }^{28}$ If we estimate the more parsimonious regression specification of Laubach (2003) — which includes only the projected federal debt, projected real GDP growth, and the equity premium - then the results imply that a one-percentage-point (relative to GDP) increase in CBO's five-year-ahead projection of federal debt increases the real five-year-ahead ten-year Treasury yield by a bit more than five basis points, which replicates his estimate. This estimate is more than two basis points larger than when the larger set of other explanatory variables is used, as in the first column of Table 2, suggesting that part of Laubach's estimated effect of projected debt reflected inadequate control for other current macroeconomic factors that determine the real interest rate. Thus, the operating assumption that using forward-looking measures of federal government debt and interest rates omits any effects of current economic conditions and policies from the empirical estimate appears to be invalid.

${ }^{29}$ If the oil price, defense shock, and Federal Reserve Treasury holding variables are not included, as in Laubach, then the coefficient on the projected real GDP growth rate variable is estimated with the expected sign (positive) and is statistically significant from zero.
} 
Coefficient estimates obtained by regressing the change in the real five-yearahead ten-year Treasury yield on the CBO's five-year-ahead projection of the federal government deficit (relative to GDP) and the other variables are reported in the second column of Table 2. The results imply that a one-percentage-point (relative to GDP) increase in CBO's five-year-ahead projection of the federal government deficit increases the change in the real five-year-ahead ten-year Treasury yield by about three basis points, but the estimate is not statistically significantly different from zero.

In the third column, the regression results suggest that a one-percentage-point (relative to GDP) increase in CBO's five-year-ahead projection of the federal government deficit increases the real five-year-ahead ten-year Treasury yield by about 18 basis points, and the estimate is statistically significantly different from zero. ${ }^{30}$ As we noted earlier, however, this specification is not consistent with one implied by an economic model of crowding out, so interpreting this result is difficult. The stock of federal debt is most relevant for determining the level of the interest rate, and the deficit, which represents only the most recent period's change in the debt, does not contain all relevant information — specifically, prior accumulated federal debt—contained in the measure of total federal debt. However, because CBO's projections of federal deficits (as a percentage of GDP) are closely correlated with their projections of federal debt (as a percentage of GDP) — the correlation coefficient between these two series is 0.89 over the sample period - then the coefficient estimate on the smaller deficit component also picks

\footnotetext{
${ }^{30}$ If the set of independent variables includes only the projected federal deficit, projected real GDP growth, and the equity premium, as in Laubach (2003), then the regression results imply that a one-percentage-point (relative to GDP) increase in CBO's five-year-ahead projection of federal deficit increases the real fiveyear-ahead ten-year Treasury yield by 28 basis points, which replicates his estimate. This estimate is almost ten basis points larger than when the larger set of other explanatory variables is used in the third column of Table 2 .
} 
up the effect of prior accumulated government debt, and the coefficient estimate is larger than when total government debt is used.

The results in Table 2 indicate that the estimated effect of projected federal government debt or deficits on a forward-looking measure of the real interest rate depends importantly on the specification. The estimates for the two specifications consistent with the analytical model of crowding out presented earlier imply that an increase in federal government debt of one percent of GDP raises the real interest rate by, at most, about three basis points.

\section{C2. Current Interest Rates and Expected Federal Government Debt}

In this section we employ a measure of the current real ten-year Treasury yield in our analysis while all of the other variables remain the same as in the previous section. The nominal ten-year Treasury yields over the months that the CBO projections were released were then adjusted for expected inflation to construct the current real interest rates used in this section of our analysis. ${ }^{31}$

The first column of Table 3 reports the coefficient estimates when regressing the level of the real ten-year Treasury yield on the five-year-ahead projection of federal government debt (relative to GDP) made by the $\mathrm{CBO}$, along with the other explanatory variables. The estimates imply that a one-percentage-point increase in the expected federal government debt-to-GDP ratio increases the current real ten-year Treasury yield by a little more than three basis points, and is statistically significantly different from zero. This estimate is about one-half of one basis point larger than when the forward-

\footnotetext{
${ }^{31}$ We obtained data for the nominal ten-year Treasury from the Federal Reserve Board, and the data for average inflation expectations from the Livingston Survey maintained by the Federal Reserve Bank of Philadelphia.
} 
looking real ten-year Treasury yield was used in the specification reported in the first column of Table 2 .

The coefficient estimates for the specification regressing the change in the current real ten-year Treasury yield on CBO's five-year-ahead projection of the federal government deficit (relative to GDP), along with the other variables, are reported in the second column of Table 3. Similar to the estimate in the first column, the estimated coefficient on the projected deficit variable implies that a one-percentage-point increase in CBO's projection of the federal government deficit (relative to GDP) increases the current real ten-year Treasury yield by about three basis points, but here this estimate is not statistically significantly different from zero. In contrast, when instead the level of the current real ten-year Treasury yield is regressed on CBO's projection of the federal government deficit, the estimated relationship suggests that increasing the expected federal deficit-to-GDP ratio by one by one percentage point causes the current real tenyear Treasury yield to increase by almost 24 basis points. While this estimate is statistically significant from zero, it is far larger than the benchmark calculations presented in Table 1, and it is also about five basis points larger than the corresponding estimate in Table 2 in which the forward-looking measure of the real ten-year was used. However, as discussed previously, this specification is not consistent with an economic model of crowding out. The coefficient estimate on the deficit is larger because it also incorporates the effect of prior accumulated federal government debt that is included in the total federal debt variable in the first column but is not included when just using the deficit measure in the third column. 
The results in Table 3 indicate that the estimated effect of projected federal government debt or deficits on a current measure of the real interest rate are only a bit larger than those in which the forward-looking measure of the real interest rate was employed in estimating the results in Table 2. However, the forward-looking measure of the real interest rate may be a better measure for trying to separate the effect of current economic conditions on the interest rate and isolate the effect of expected federal government debt on real interest rates.

As before, the estimated results also depend importantly on the specification of the regression equation. The coefficient estimates derived using the two specifications of real interest rates consistent with a an economic model of crowding out - the first two columns - imply that federal government debt may have a statistically significant effect on the level of real interest rates (or not, as shown in second column), but, if so, the effect - about 3 basis points for an increase in the debt of one percent of GDP - is consistent with benchmark calculations presented earlier.

\section{C3. Current Interest Rates and Current Federal Government Debt}

While using expected measures of interest rates and federal debt is a much more theoretically appealing approach to estimating the relationship between these variables, many previous studies have used only current measures federal debt and interest rates. Thus it is informative to estimate the effects of current federal debt on current real tenyear Treasury yields in order to compare the results to those of the prior sections. 
To do so, we replace the data for CBO's annual projections of federal government debt and deficits with data on current federal government debt and borrowing. ${ }^{32}$ We also replace CBO's projections for the rate of growth in real GDP with current real GDP growth rates. The current real ten-year Treasury yield measure reflects the prevailing rate at the end of each year and is constructed the same as in the prior section. ${ }^{33}$ All of the other variables are the same as in the previous analysis.

As we show in the first column of Table 4, when using current federal government debt (relative to GDP) and a measure of the current real ten-year Treasury yield, the regression results imply that a one-percentage-point increase in the federal debt-to-GDP ratio is estimated to increase the real ten-year Treasury rate by a little less than five basis points, but the coefficient estimate is not statistically significantly different from zero. ${ }^{34}$ The second column reports estimates for the regression equation where the change in the real ten-year Treasury yield is regressed on federal borrowing. The results imply that a one-percentage-point increase in federal government borrowing (relative to GDP) increases real ten-year Treasury rates by seven basis points, but again this estimate is not statistically significantly different from zero.

Alternatively, if the level of the real ten-year Treasury yield is regressed on this measure of federal government borrowing, the coefficient estimates shown in the third column imply that a one-percentage-point increase in the federal government borrowingto-GDP ratio increases the real ten-year Treasury rate by about nine basis points,

\footnotetext{
32 These data are from the Federal Reserve Board's Flow of Funds Accounts. Because the time period of the data is not limited by the availability of CBO projections, we extend the data back to 1953 .

${ }^{33}$ The timing is adjusted slightly so that it reflects the prevailing interest rate at the end of the year (December) rather than the month when the $\mathrm{CBO}$ projections are released (which is typically in the following month of January).

${ }^{34}$ Preliminary estimates of this equation revealed the presence of serially correlated errors so the regression results reported here are for estimates with an $\mathrm{AR}(1)$ corrected specification of the residuals.
} 
although this effect is not statistically significantly different from zero as in the first two specifications. This estimate of the empirical relationship between federal government borrowing and the level of the real ten-year Treasury yield in Table 4 is markedly smaller than the corresponding estimates in Tables 2 and 3, which used forward-looking measures of federal government borrowing and the real interest rate. Unlike the strong positive correlation between CBO's projected measures of federal debt and the deficit, there is not a positive correlation between actual federal debt and borrowing (both measured as a percent of GDP); the correlation coefficient is -0.13 for these two series.

\section{C4. Vector Autoregressions}

An alternative approach to the reduced-form equation estimation used in our analysis above is to estimate the relationship between federal government debt, or federal government borrowing, and the level of the real ten-year Treasury rate in a VAR framework. This methodology has been used in a number of empirical studies of the relationship between federal government debt and borrowing.

In estimating the VARs, we use the same data as those in the first and third columns of Tables 2 through 4; thus we analyze the effect of a measure of the federal debt on the level of the interest rate and the effect of a measure of the federal deficit on the level of the interest rate. A useful way to analyze the results of the VAR estimates is to look at the impulse responses generated from these estimates. The corresponding impulse responses stemming from VAR estimates using projected federal government debt and the five-year ahead measure of the ten-year real Treasury rate are shown in Figure 15, and Figure 16 shows the impulse responses when the projected federal 
government deficits (instead of debt) is used in the VAR. The ordering of the variables that is used to generate these impulse responses is the same as the order of the charts in each figure: real oil prices, military buildup shocks, Treasury security holdings (or purchases) by the Federal Reserve, projected federal government debt (or deficits), the equity premium, and the projected real GDP growth rate. The charts of the impulse responses also include the plus or minus two-standard-error bands, using Monte Carlo standard errors.

In Figure 15, the second chart from the top on the right side shows the response of the five-year-ahead real ten-year Treasury rate from a one-standard deviation shock to projected federal government debt. The response of the forward-looking measure of the real interest rate to an increase in projected federal debt (relative to GDP) is positive and statistically significant in the first period. A one-standard deviation shock in the projected federal debt-to-GDP ratio, which is equal to 16.3 percent, is estimated to increase the forward-looking real interest rate by 26.6 basis points. Thus, this estimate implies that an increase in federal debt equal to one percent of GDP causes the real interest rate to increase by about $1 \frac{1}{2}$ basis point, which is somewhat smaller than the corresponding estimate from the reduced form regression results in Table 2 but is still consistent with the theoretical calculations presented in Table 1. As shown in the corresponding variance decomposition presented in Table 5, only 10 percent of the variation in the forward-looking measure of the real interest rate is due to the innovation in projected federal debt.

Figure 16 shows the impulse responses from the VAR estimates when the projected federal government deficit (relative to GDP) is used instead of federal 
government debt. An increase in the projected federal government deficit is estimated here to have a positive effect on the five-year-ahead measure of the real ten-year Treasury yield and is statistically significantly different from zero in the first period. A onestandard deviation shock in the projected federal deficit-to-GDP ratio, which is equal to 3 percent, is estimated to increase the forward-looking real interest rate by 36.6 basis points. Thus, this estimate implies that an increase in the federal deficit equal to one percent of GDP causes the real interest rate to increase by about 12 basis points, which is somewhat smaller than the corresponding estimate from the reduced form regression results in Table $2 .{ }^{35}$ However, this specification is not consistent with our analytical model of crowding out, and the estimated effect is much larger than the benchmark calculations presented in Table 1. The estimated effect of the projected deficit also is larger than the effect of the projected federal debt, as in the reduced-form regression estimates in Table 2, but, as explained above, this is because the projected deficit variable is strongly correlated with the projected debt variable and the deficit variable does not include the relevant information on prior accumulated federal debt.

Figures 17 and 18 show the impulse responses of the current real ten-year Treasury rate to innovations in the projected measures of federal debt and deficits along with our other explanatory variables. The second chart from the top on the right side of Figure 17 shows the impulse response of the current real ten-year Treasury rate from a one-standard deviation shock to projected federal government debt. The projected federal debt is estimated to have a positive and statistically significant effect on the current real interest rate. A one-standard deviation shock in the projected federal debt-to-

\footnotetext{
${ }^{35}$ As shown in the corresponding variance decomposition presented in Table 6, about 28 percent of the variation in the forward-looking measure of the real interest rate is due to the innovation in projected federal deficit.
} 
GDP ratio (equal to 16.3 percent) is estimated to increase the current real interest rate by 40 basis points. Thus, this estimate implies that an increase in federal debt equal to one percent of GDP causes the current real interest rate to increase by about $2 \frac{1}{2}$ basis points. This estimate is somewhat smaller than the corresponding estimate from the reduced form regression results in Table 3 but is still consistent with the theoretical calculations presented in Table 1. As shown in the corresponding variance decomposition presented in Table 7, about 37 percent of the variation in the current real interest rate is due to the innovation in projected federal debt.

As shown in Figure 18, the effect of the projected federal deficit on the current real interest rate is positive but not statistically significantly different from zero, in contrast to both the results in Figure 16 when the forward-looking measure of the real interest rate was used and the corresponding estimate from the reduced form regression results in Table 3. Figures 19 and 20 also show that innovations in the current federal debt, or current federal borrowing, have effects on the current real interest rate that are not statistically significantly different from zero. These results are similar to the corresponding estimates shown in Table 4 for our reduced-form regression analysis.

In general, our analysis of the effect of federal government debt on the real interest rate using VAR analysis are fairly similar to the results we find from our reduced-form regression estimates. Projected measures of the federal debt tend to have a statistically significant, positive effect on forward-looking or current real interest rates; an increase in the projected federal debt equal to one percent of GDP is estimated to increase the real interest rate by about two to three basis points. However, current measures of the federal debt do not have a statistically significant effect on current real interest rates. 


\section{Conclusions}

As we noted at the outset, the recent reemergence of U.S. federal government budget deficits has focused attention on an old question: Does government debt affect interest rates? Despite a substantial body of empirical analysis, the answer based on the past two decades of research is mixed. While some studies suggest a small increase of in the real interest rate when federal debt increases, others estimate large effects, and some studies find no statistically significant interest rate effect. Comparing results across studies is complicated by differences in economic models, definitions of "government debt" and "interest rates," econometric approaches, sources of data, and rhetoric.

Using a standard set of data and a simple economic framework, we reconsider and add to empirical evidence on the effect of federal government debt and interest rates. We begin by deriving analytically the effect of government debt on the real interest rate and conclude that an increase in government debt equivalent to one percent of GDP would be predicted to increase the real interest rate by about two to three basis points. While some existing studies estimate effects in this range, others find larger effects. In virtually all cases, larger estimates come from specifications relating federal deficits (as opposed to debt) and the level interest rates (as opposed to changes in interest rates).

We present our own empirical analysis in two parts. First, we examine a variety of conventional reduced-form specifications linking interest rates and government debt and other variables. In particular, we provide estimates for three types of specifications to permit comparisons among different approaches taken in previous research; we estimate the effect of: (1) an expected, or projected, measure of federal government debt 
on a forward-looking measure of the real interest rate; (2) an expected, or projected, measure of federal government debt on a current measure of the real interest rate; and (3) a current measure of federal government debt on a current measure of the real interest rate. Most of the statistically significant estimated effects are consistent with the prediction of our economic model calculations. Second, we provide evidence using vector autoregression analysis. In general, these results are similar to those found in our reduced-form econometric analysis and consistent with the analytical calculations.

Taken together, the bulk of our empirical results suggest that an increase in federal government debt equivalent to one percent of GDP, all else equal, would be expected to increase the long-term real rate of interest by about three basis points, while some estimates are not statistically significantly different from zero. By presenting a range of results with the same data, we illustrate the dependence of estimation on specification and definition differences.

This paper is deliberately narrow in its scope; our focus, as the paper's title suggests, is only on the interest rate effects of government debt. The effect of debt and deficits on interest rates has been the focus of much of the recent and previous policy discussions concerning the effects of government borrowing on investment and economic activity. However, we do believe that other effects of federal debt and deficits on economic factors other than interest rates are important topics for analysis. We have not investigated the degree to which federal borrowing might be offset by private domestic saving or inflows of foreign saving or both. These factors interact with federal borrowing 
in ways that may have similar effects on interest rates but different effects on the overall economy. ${ }^{36}$

Our findings should not be construed as implying that "deficits don't matter." Substantially larger, persistent, and unsustainable levels of government debt can eventually put increasing strains on the available domestic and foreign sources of loanable funds, and can represent a large transfer of wealth to finance current generations' consumption from future generations which much eventually pay down federal debt to a sustainable level. Holding the path of non-interest government outlays constant, deficits represent higher future tax burdens to cover both these outlays plus interest expenses associated with the debt, which have adverse consequences for economic growth. In the United States at the present time, unfunded implicit obligations associated with the Social Security and Medicare programs are particularly of concern. ${ }^{37}$

\footnotetext{
${ }^{36}$ Recent federal income tax reductions have also rekindled interest in the impact of deficits on consumption. Shapiro and Slemrod (2003) and Johnson, Parker, and Souleles (2004) investigate the impact of deficit-increasing tax reductions on household consumption.

${ }^{37}$ See Congressional Budget Office (2003) and Gokhale and Smetters (2003), for example, for recent discussions of the potentially large unfunded obligations associated with these entitlement programs.
} 


\section{References}

Auerbach, Alan J., 2003, "Fiscal Policy, Past, and Present," National Bureau of Economic Research, Working paper \#10023, October.

Ball, Laurence, and N. Gregory Mankiw, 1995, "What Do Budget Deficits Do?" Proceedings, Federal Reserve Bank of Kansas City, pp. 95-149.

Barro, Robert J., 1989, "The Neoclassical Approach to Fiscal Policy.” In Robert J. Barro (ed.), Modern Business Cycle Theory, Cambridge, MA: Harvard University Press, pp. 178-235.

Barro, Robert J., 1991, “World Interest Rates and Investment,” National Bureau of Economic Research, Working paper \#3849, September.

Barro, Robert J., and Xavier Sala-i-Martin, 1990, "World Real Interest Rates," National Bureau of Economic Research, Working paper \#3317, April.

Barth, James R., George Iden, and Frank S. Russek, 1984, "Do Federal Deficits Really Matter?” Contemporary Policy Issues vol. 3, no. 1 (Fall), pp. 79-95.

Barth, James R., George Iden, Frank S. Russek, and Mark Wohar, "The Effects of Federal Budget Deficits on Interest Rates and the Composition of Domestic Output." In Penner, Rudolph G. (ed.), The Great Fiscal Experiment, Washington, DC: The Urban Institute Press, pp. 71-141.

Baxter, Marianne, and Robert G. King, 1993, "Fiscal Policy in General Equilibrium," American Economic Review vol. 83, no. 3 (June), pp. 315-334.

Bernheim, B. Douglas, 1987, "Ricardian Equivalence: An Evaluation of Theory and Evidence." In Stanley Fischer (ed.), NBER Macroeconomics Annual, Cambridge: MIT Press, pp. 263-304.

Bernheim, B. Douglas, 1989, “A Neoclassical Perspective on Budget Deficits," Journal of Economic Perspectives vol. 3, no. 2 (Spring), pp. 55-72.

Blanchard, Olivier J., and Roberto Perotti, 2000, “An Empirical Characterization of the Dynamic Effects of Changes in Government Spending and Taxes on Output," Mimeograph, MIT.

Bohn, Henning, 1998, "The Behavior of U.S. Public Debt and Deficits," Quarterly Journal of Economics vol. 113, no. 3 (August), pp. 949-963.

Calomiris, Charles, Eric M. Engen, Kevin Hassett, and R. Glenn Hubbard, 2003, “Do Budget Deficit Announcements Move Interest Rates?” Mimeograph, American Enterprise Institute and Columbia University, December. 
Cebula, Richard J., and James V. Koch, 1989, "An Empirical Note on Deficits, Interest Rates, and International Capital Flows," Quarterly Review of Economics and Business vol. 29, no. 3 (Autumn), pp. 121-127.

Cebula, Richard J., and James V. Koch, 1994, "Federal Budget Deficits, Interest Rates, and International Capital Flows: A Further Note," Quarterly Review of Economics and Finance vol. 34, no. 1 (Spring), pp. 117-120.

Cohen, Darrel, and Olivier Garnier, 1991, "The Impact of Forecasts of Budget Deficits on Interest Rates in the United States and Other G7 Countries," Mimeograph, Board of Governors of the Federal Reserve System.

Cohen, Darrel, and Glenn Follette, 2003, "Forecasting Exogenous Fiscal Variables in the United States," Finance and Economics Discussion Series 2003-59, Board of Governors of the Federal Reserve System, November. December.

Congressional Budget Office, 2003, "The Long-Term Budget Outlook,"

Congressional Budget Office, 2004, "The Uncertainty of Budget Projections: A Discussion of Data and Methods," April.

Council of Economic Advisers, 1994, Economic Report of the President, Washington, D.C.: U.S. Government Printing Office.

Council of Economic Advisers, 2003, Economic Report of the President, Washington, D.C.: U.S. Government Printing Office.

Eichenbaum, Martin, and Jonas Fisher, 2004, "Fiscal Policy in the Aftermath of 9/11," National Bureau of Economic Research, Working paper \#10430, April.

Elmendorf, Douglas W., and N. Gregory Mankiw, 1999 "Government Debt." In John B. Taylor and Michael Woodford (eds.), Handbook of Macroeconomics, Amsterdam: Elsevier Science, Chapter 25.

Elmendorf, Douglas W., 1993, “Actual Budget Deficit Expectations and Interest Rates," Mimeograph, Harvard University, March.

Elmendorf, Douglas W., 1996, "The Effect of Deficit-Reduction Laws on Real Interest Rates," Mimeograph, Board of Governors of the Federal Reserve System, October.

Evans, Charles L., and David Marshall, 2002, "Economic Determinants of the Nominal Treasury Yield Curve," Federal Reserve Bank of Chicago, Working paper \#2001-16 (revised). 
Gale, William G., and Peter Orszag, 2002, "The Economic Effects of Long-Term Fiscal Discipline," Urban Institute-Brookings Institution Tax Policy Center Discussion Paper, December.

Gale, William G., and Peter Orszag, 2003, "Economic Effects of Sustained Budget Deficits," National Tax Journal vol. 56, no. 3 (September), pp. 463-485.

Gokhale, Jagadeesh, and Kent Smetters, 2003, Fiscal and Generational Imbalances: New Budget Measures for New Budget Priorities, Washington, DC: AEI Press.

Johnson, David S., Jonathan A. Parker, and Nicholas S. Souleles, 2004, "The Response of Consumer Spending to the Randomized Income Tax Rebates of 2001," Mimeograph, Bureau of Labor Statistics, Princeton University, and University of Pennsylvania, February.

Kitchen, John, 1996, "Domestic and International Financial Market Responses to Federal Deficit Announcements," Journal of International Money and Finance vol. 15, no. 2, pp. 239-254.

Kitchen, John, 2002, "A Note on Interest Rates and Structural Budget Deficits," Mimeograph, October.

Laubach, Thomas, 2003, " New Evidence on the Interest Rate Effects of Budget Deficits and Debt," Finance and Economics Discussion Series 2003-12, Board of Governors of the Federal Reserve System, May.

McCallum, Bennett, 1984, “Are Bond-financed Deficits Inflationary? A Ricardian Analysis," Journal of Political Economy vol. 92, no. 1, pp. 123-135.

Miller, Stephen M., and Frank S. Russek, 1991, "The Temporal Causality Between Fiscal Deficits and Interest Rates," Contemporary Policy Issues vol. 9 (July), pp. 12-23.

Miller, Stephen M., and Frank S. Russek, 1996, “Do Federal Deficits Affect Interest Rates? Evidence from Three Econometric Methods," Journal of Macroeconomics vol. 18, no. 3 (Summer), pp. 403-428.

Quigley, Michael Regan, and Susan Porter-Hudak, 1994, "A New Approach in Analyzing the Effect of Deficit Announcements on Interest Rates," Journal of Money, Credit, and Banking vol. 26 (November), pp. 894-902.

Ramey, Valerie A., and Matthew D. Shapiro, 1998, “Costly Capital Reallocation and the Effects of Government Spending," Carnegie Rochester Conference Series on Public Policy vol. 48 (June), pp. 145-194.

Seater, John J., 1993, "Ricardian Equivalence," Journal of Economic Literature vol. 31 (March), pp. 142-190. 
Shapiro, Matthew D., and Joel Slemrod, 2003, "Did the 2001 Tax Rebate Stimulate Spending? Evidence from Taxpayer Surveys," in James Poterba (editor), Tax Policy and the Economy 17, Cambridge, MA: MIT Press.

Thorbecke, Willem, 1993, "Why Deficit News Affects Interest Rates," Journal of Policy Modeling vol. 15 (February), pp. 1-11.

Wachtel, Paul, and John Young, 1987, "Deficit Announcements and Interest Rates," American Economic Review 77 (December), pp. 1007-1022. 
Figure 1

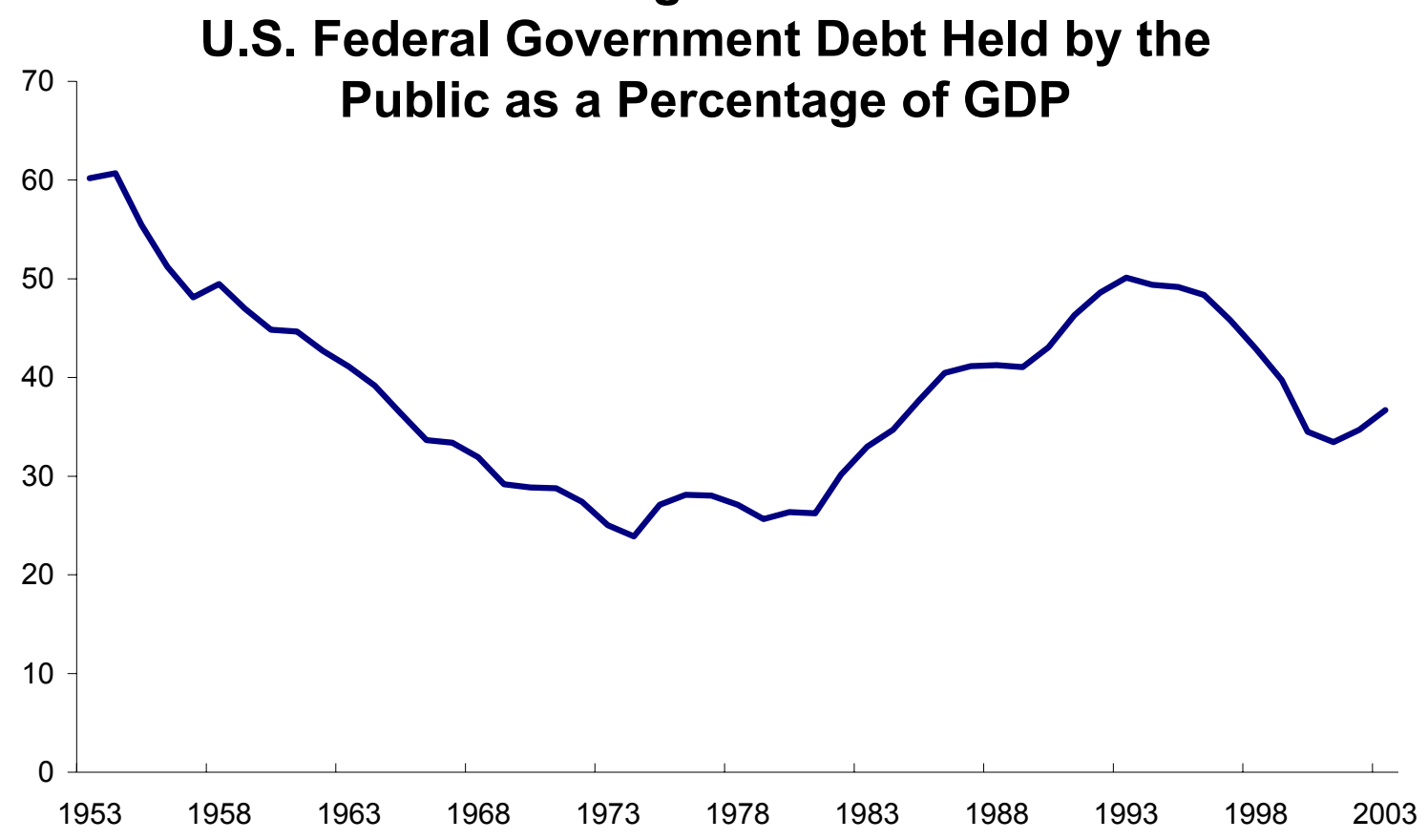

Figure 2

\section{U.S. Federal Government Borrowing as a}

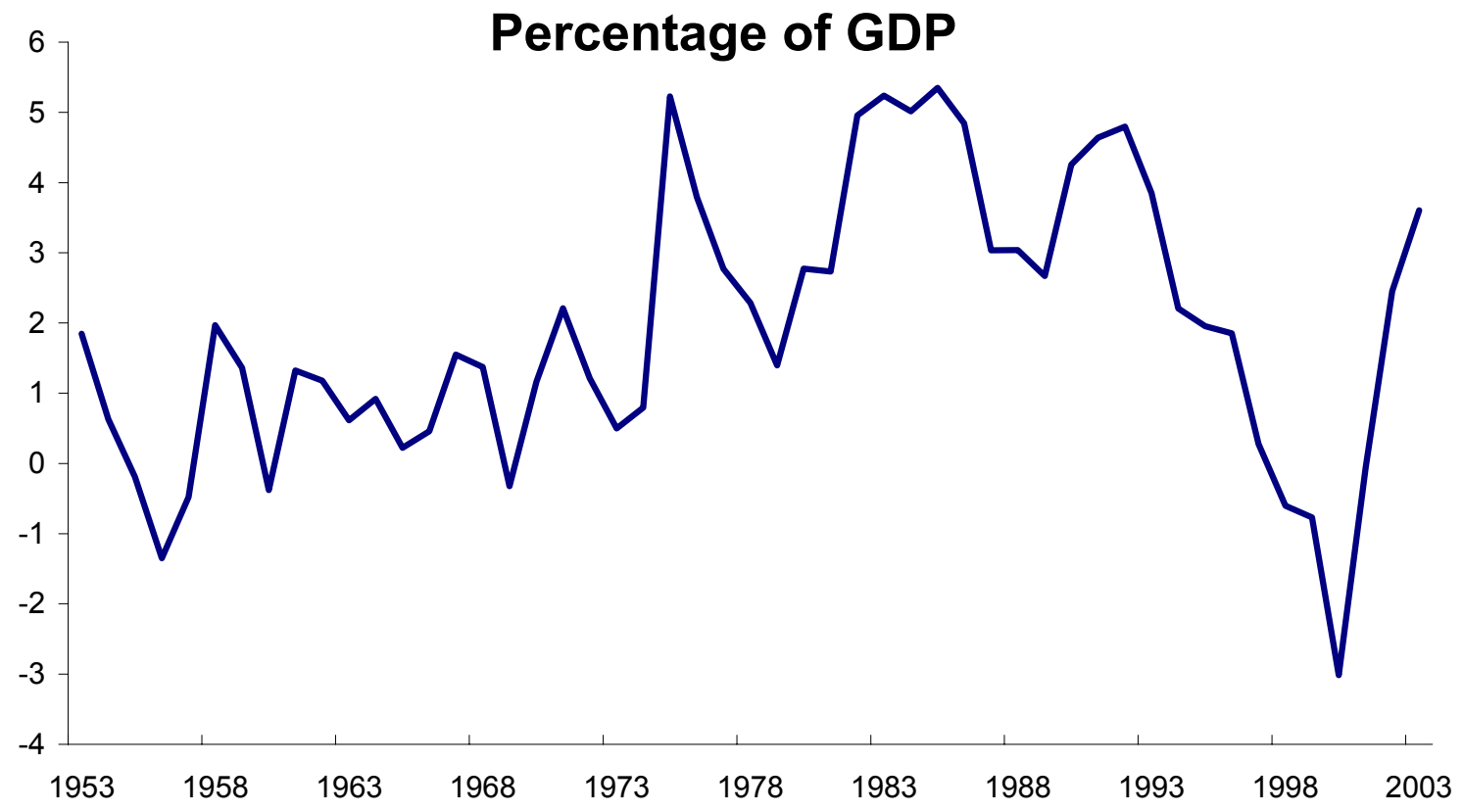


Figure 3

U.S. Federal Government Debt Held by the

Public as a Percentage of U.S. Private Capital

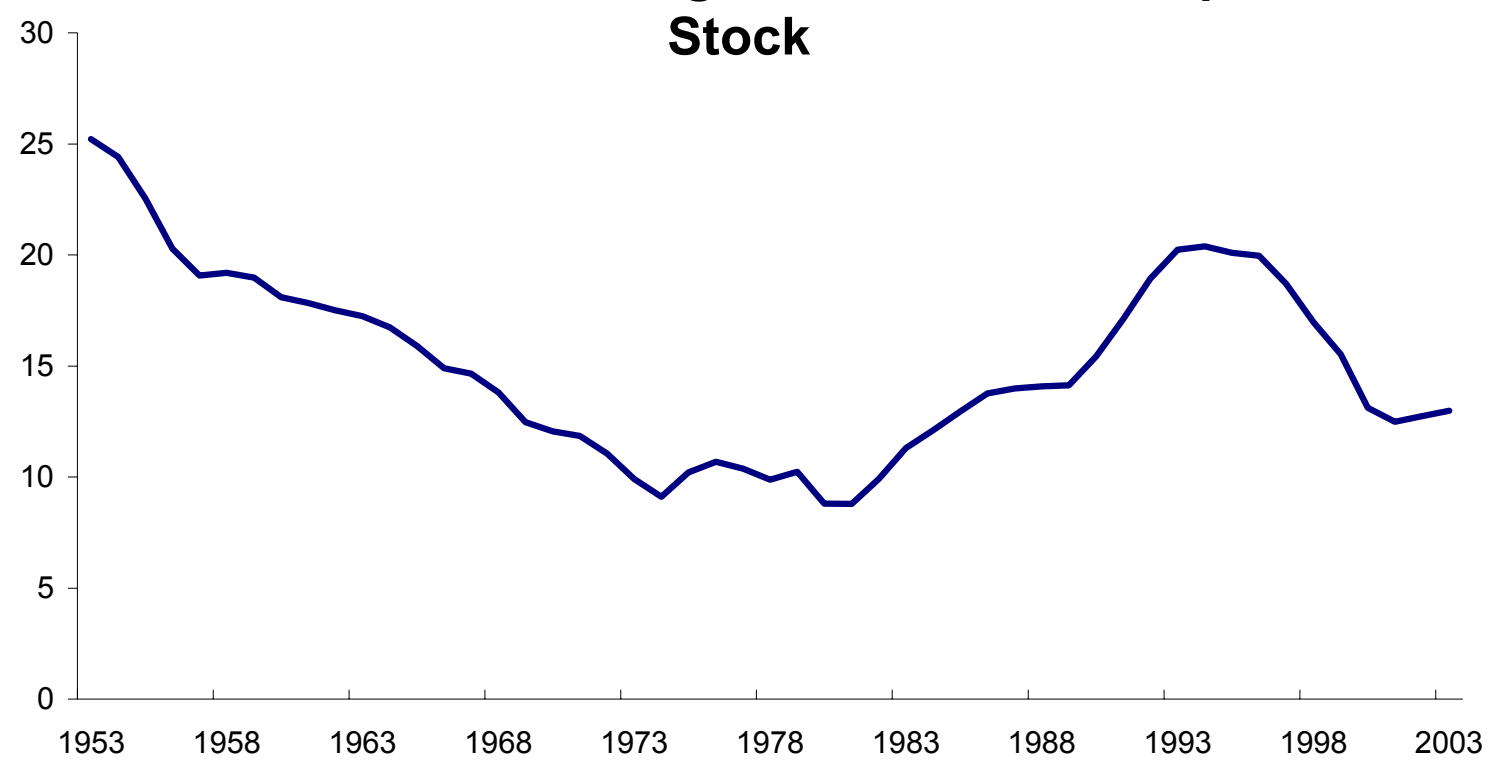

Figure 4

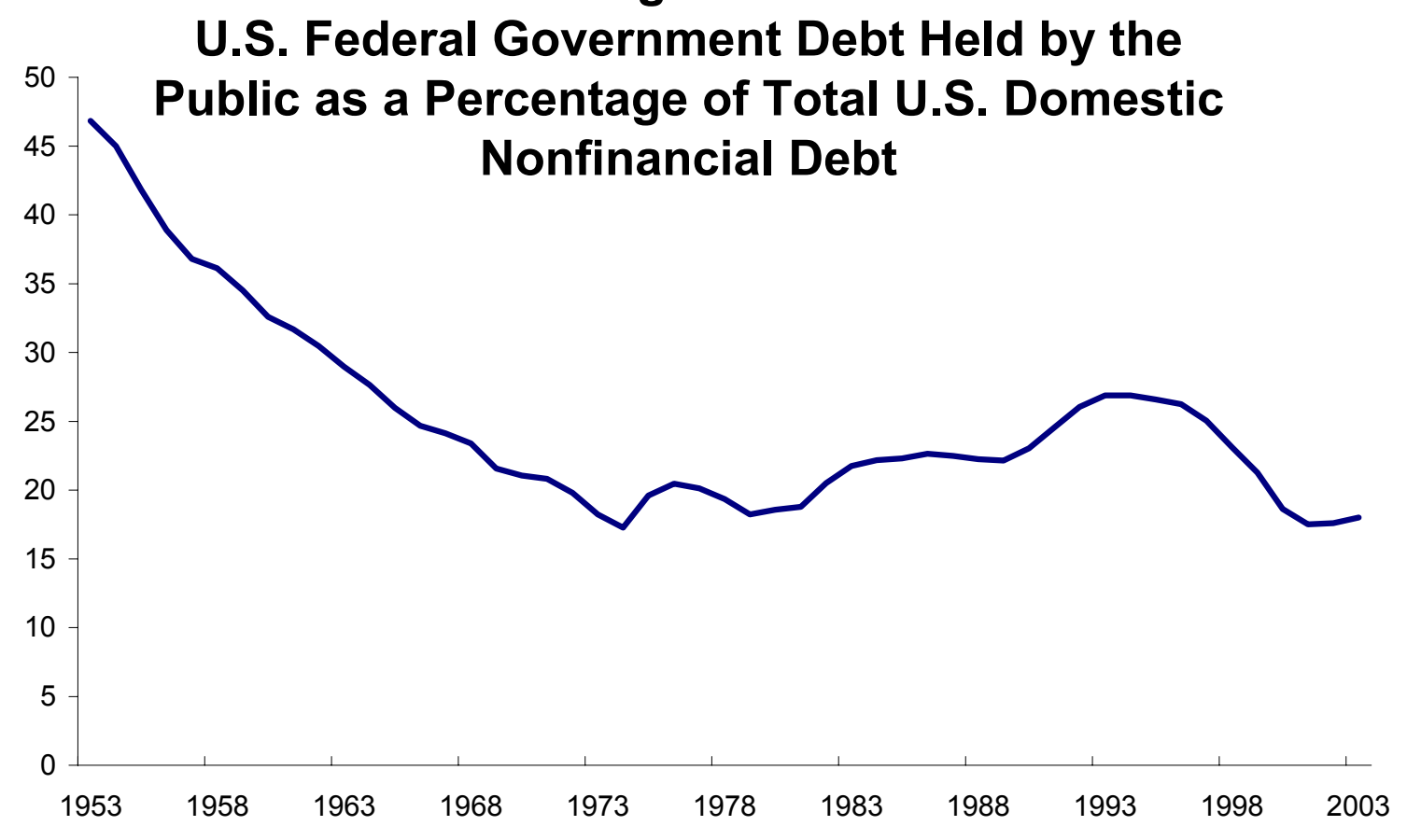


Figure 5

U.S. Federal Government Borrowing as a Percentage of Total U.S. Domestic

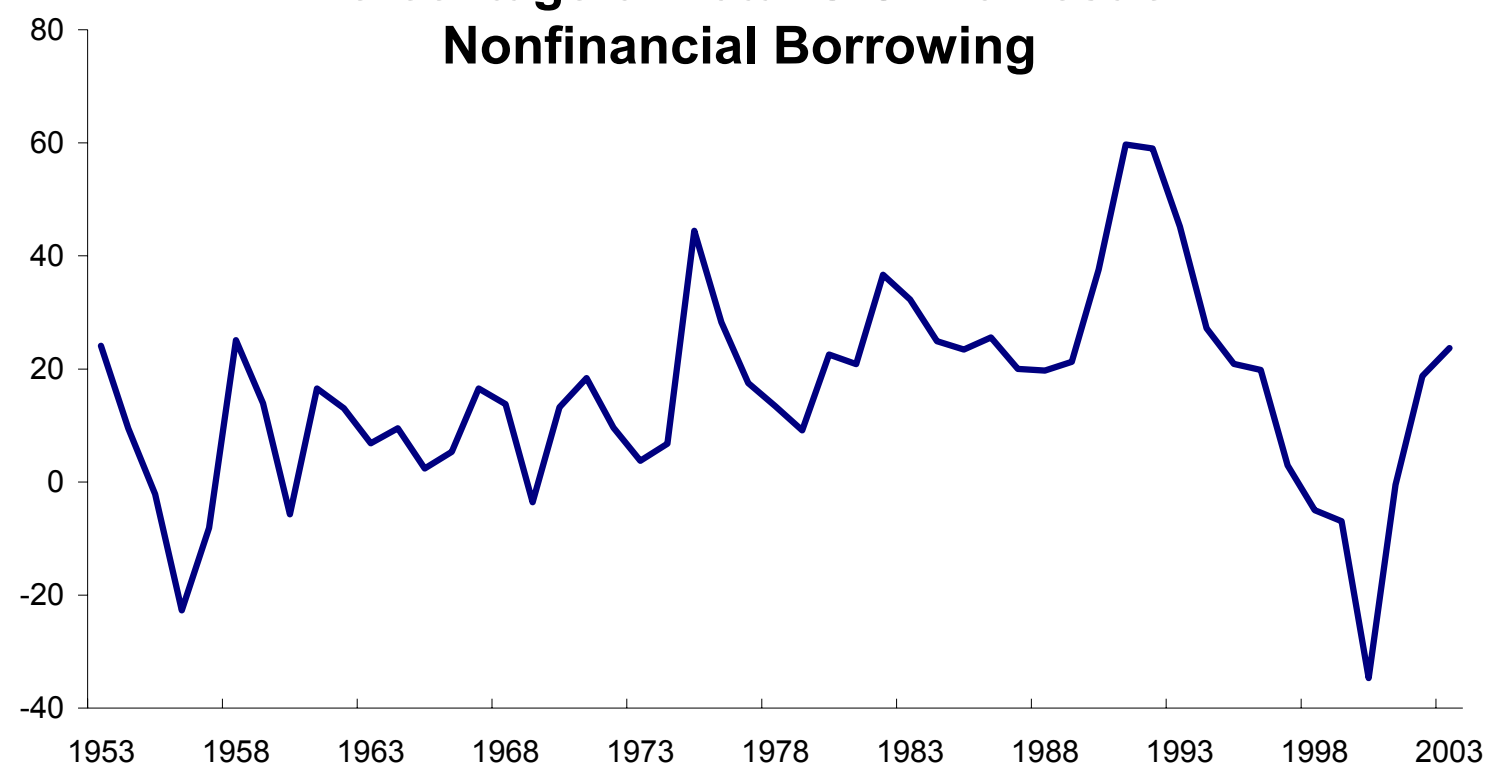

Figure 6

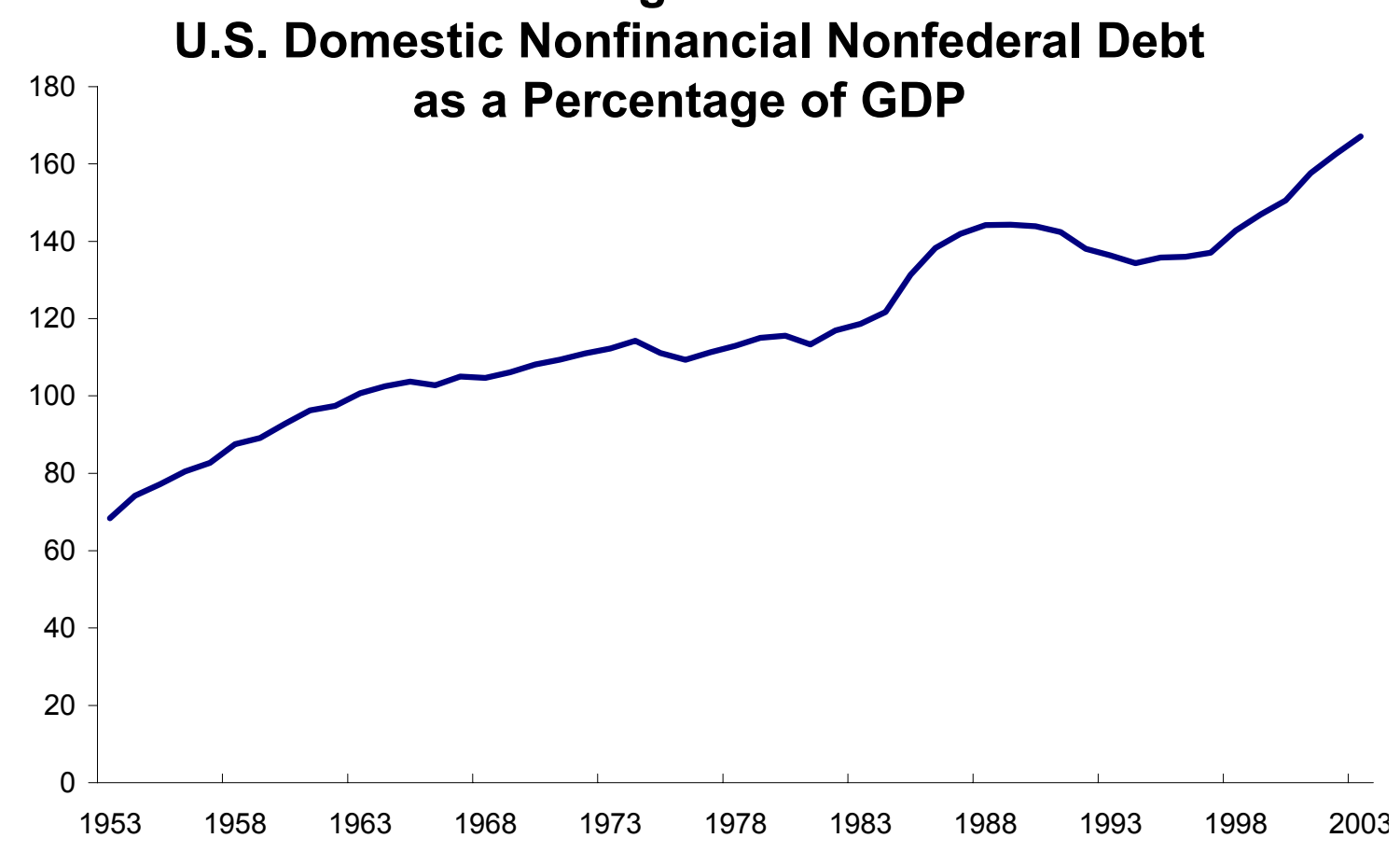


Figure 7

U.S. Domestic Nonfinancial Nonfederal

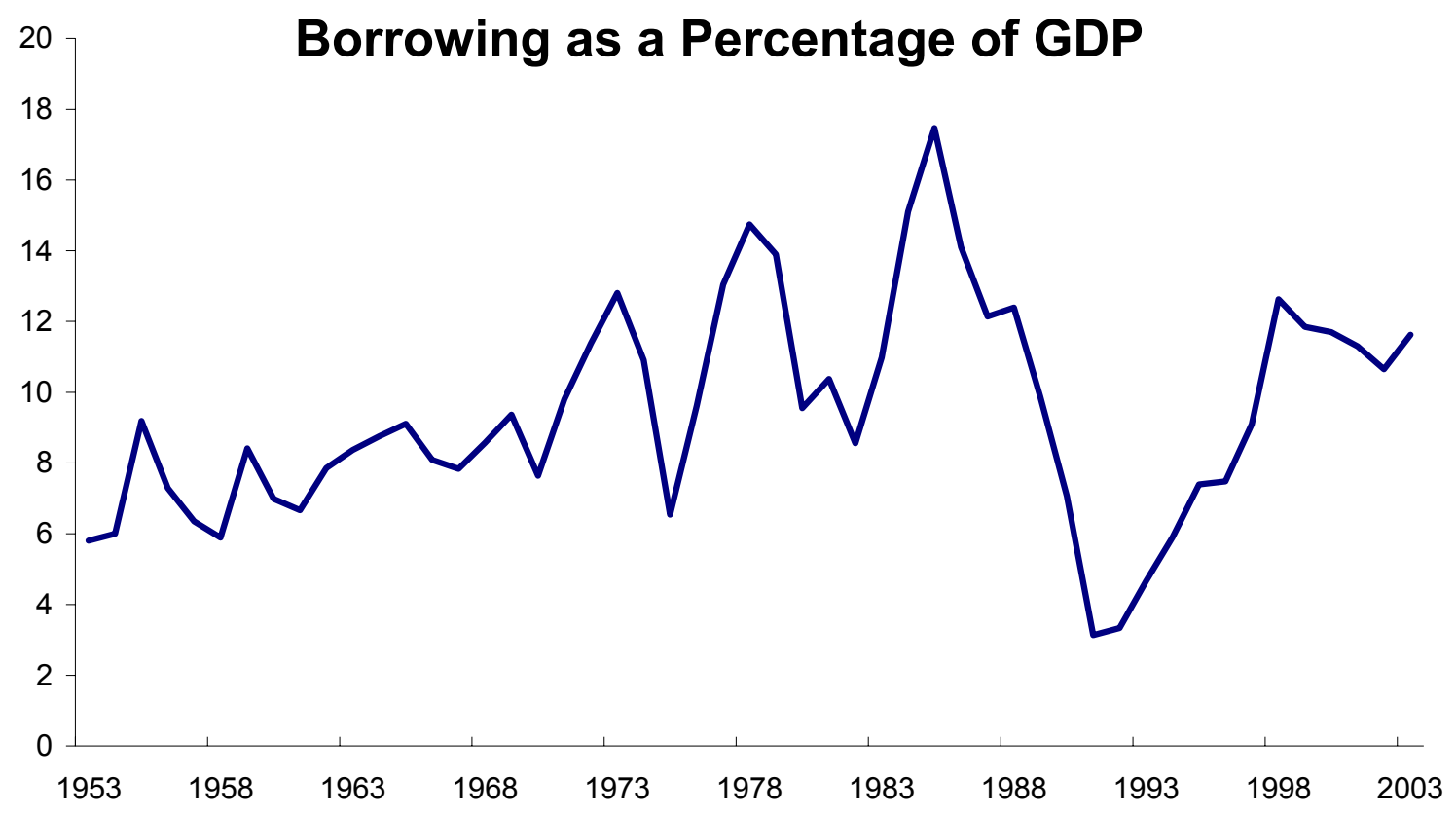

Figure 8

Foreign Holdings of U.S. Treasury Securities as a Percentage of Total U.S. Treasury

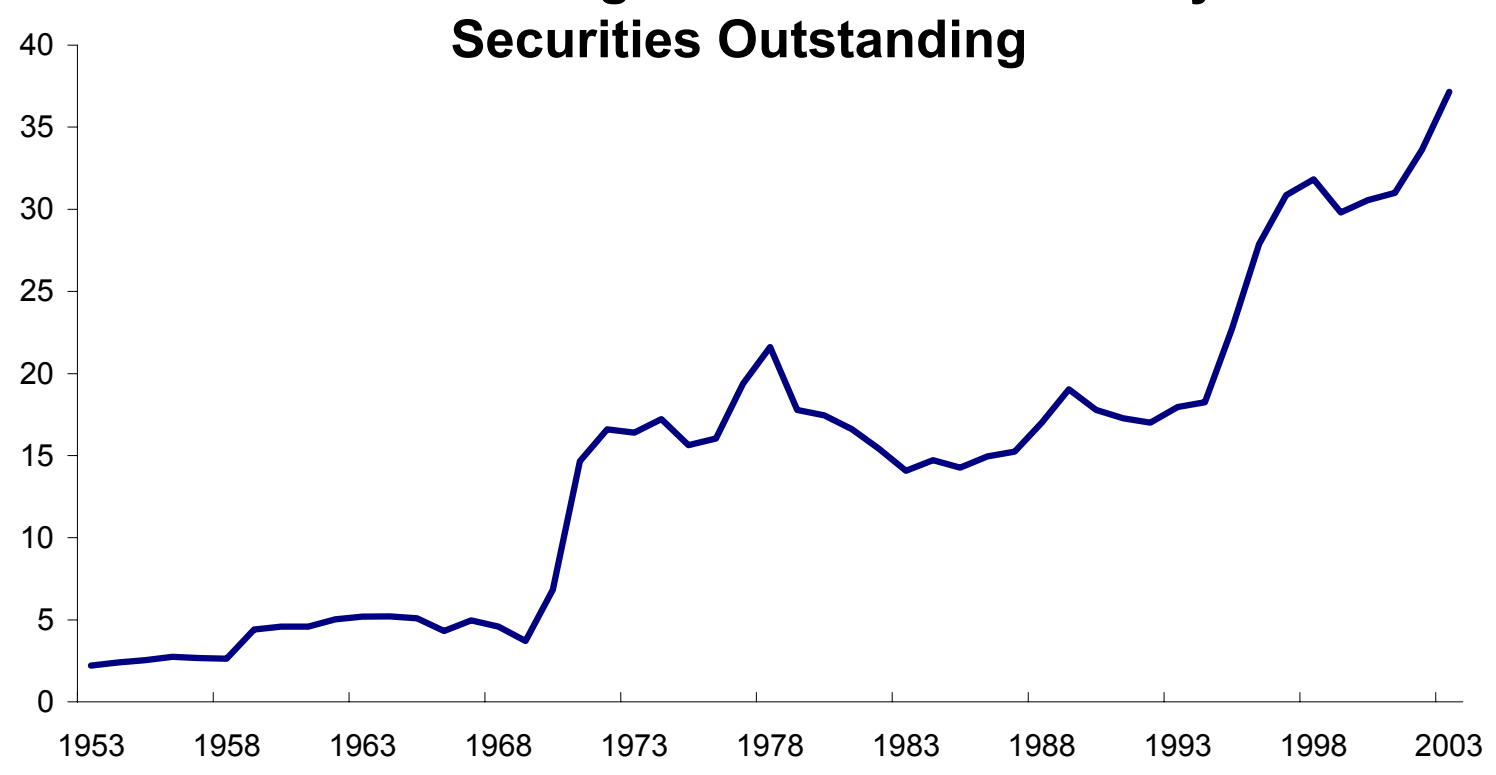


Figure 9

Federal Reserve Holdings of U.S. Treasury

Securities as a Percentage of Total U.S.

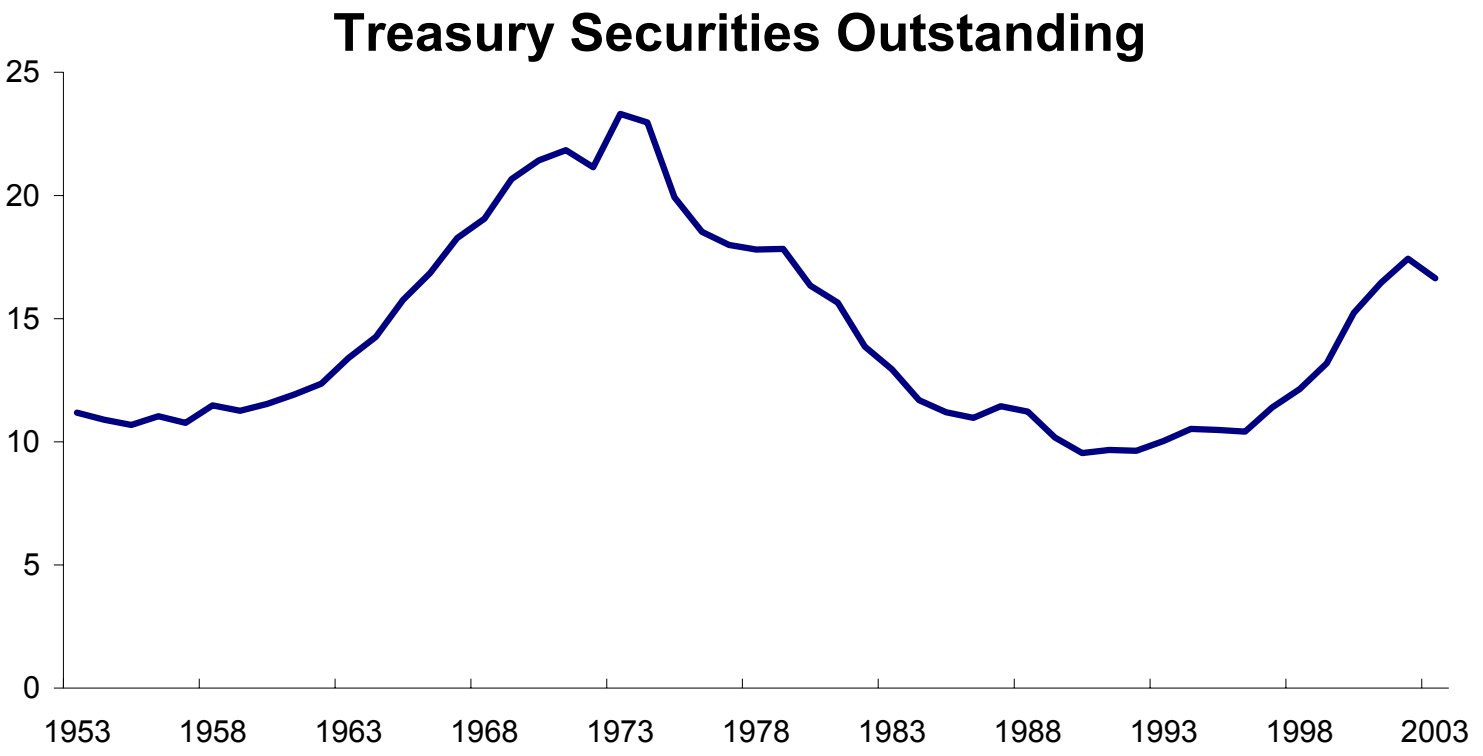

Figure 10

U.S. Federal Government Debt Held by the

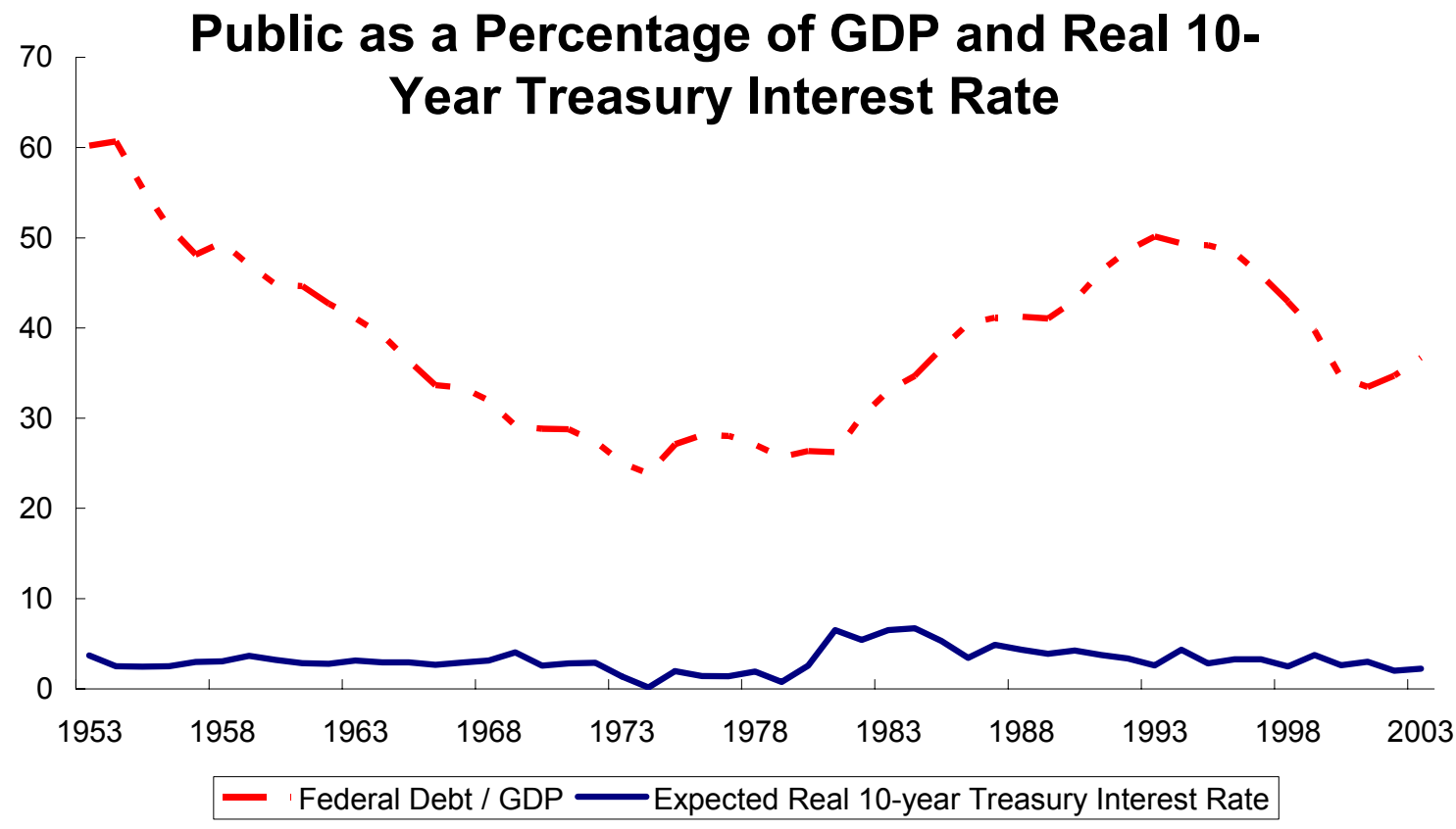


Figure 11

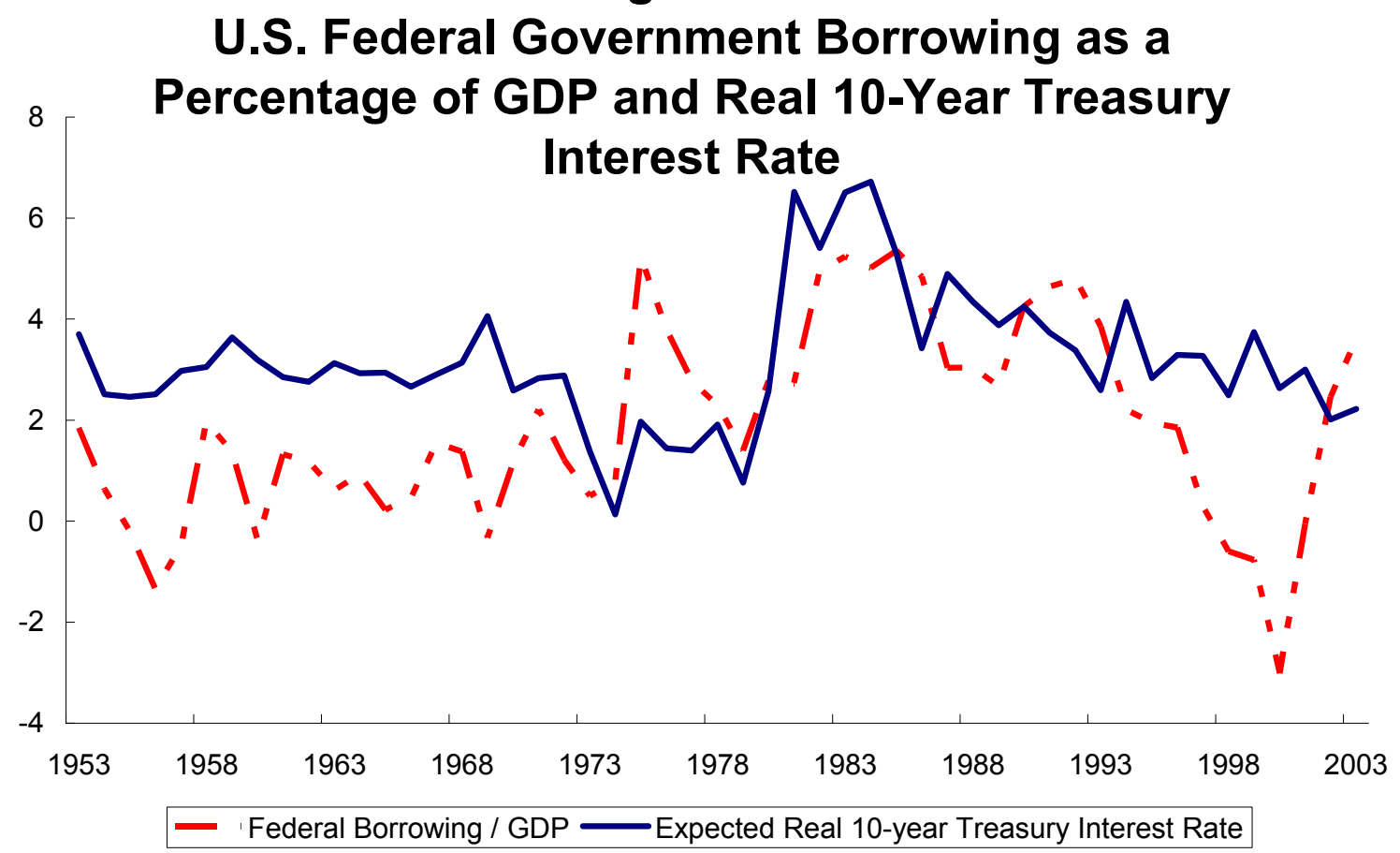

Figure 12

U.S. Federal Government Borrowing as a Percentage of GDP and the Change in the Real

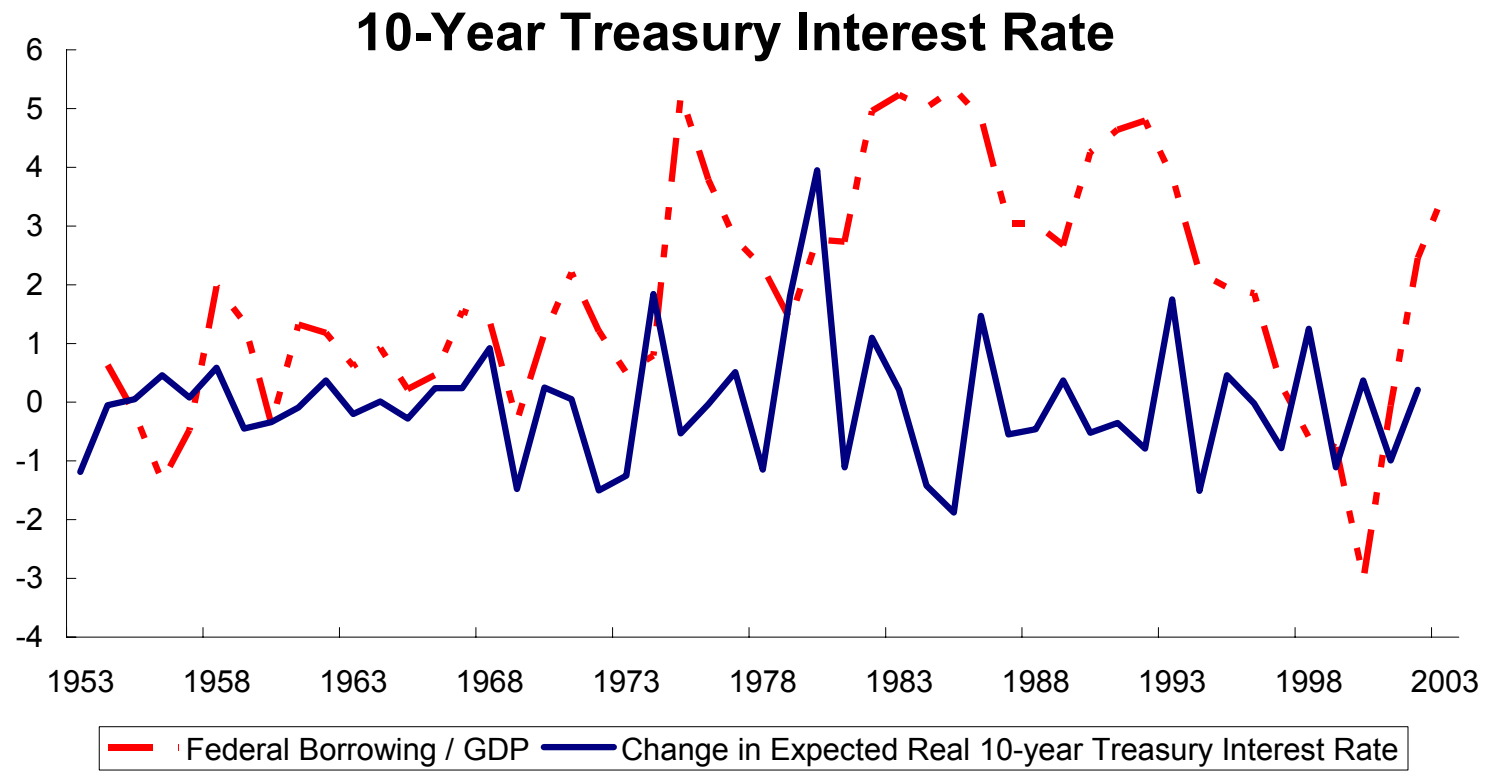


Figure 13

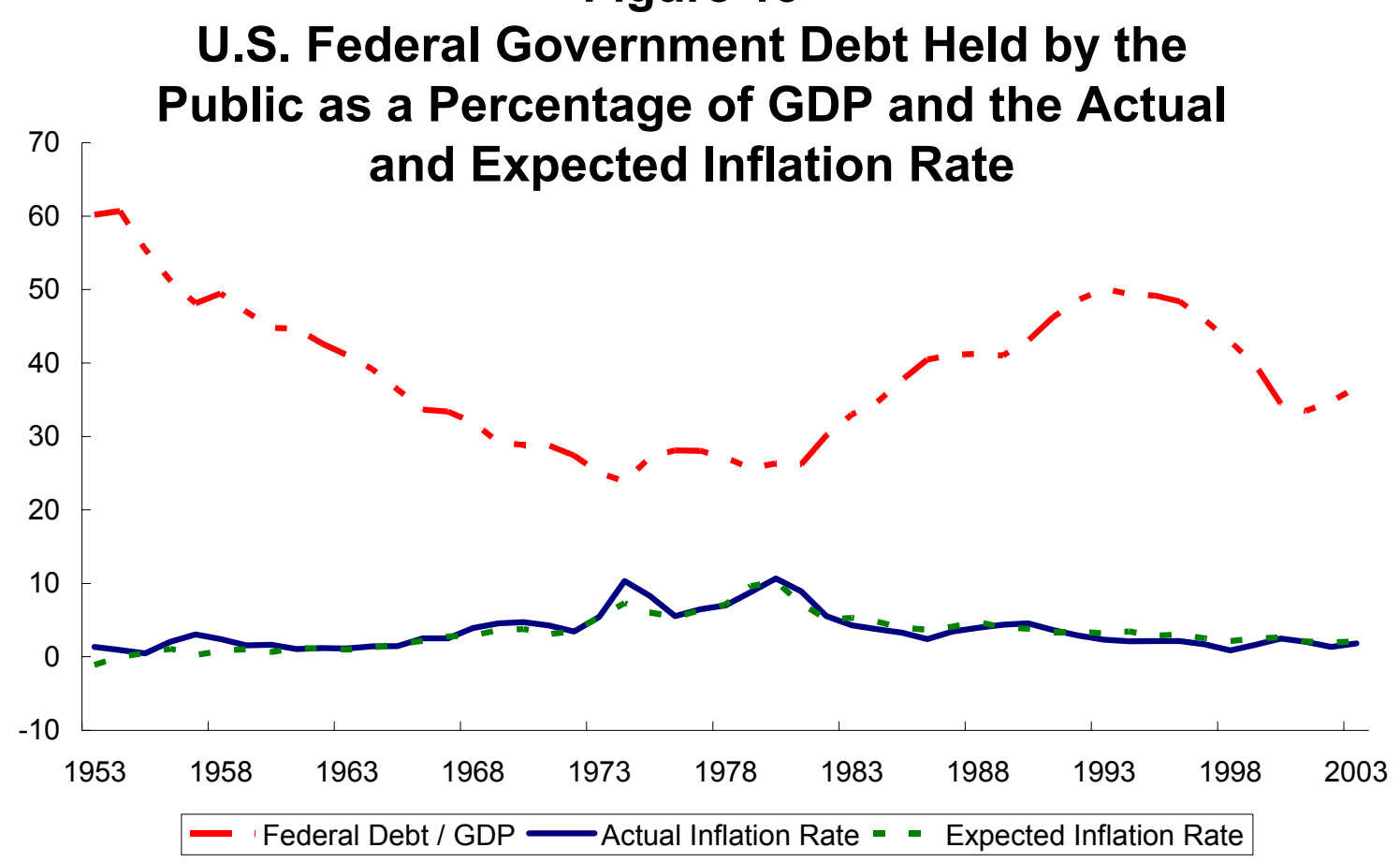

Figure 14

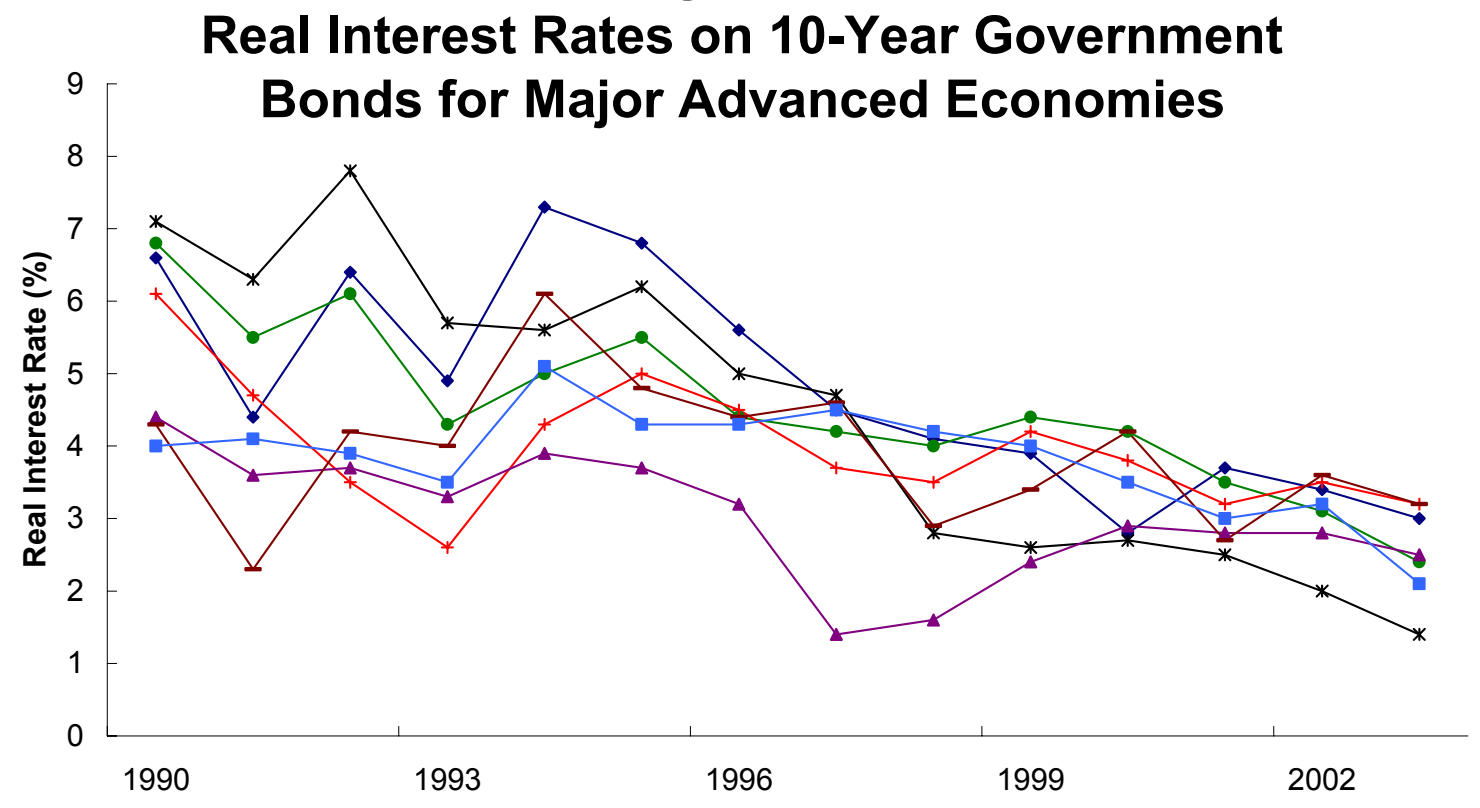

Canada $\rightarrow$-France + Germany $*$ - Italy $\rightarrow$ Japan - United Kingdom $\rightarrow-$ United States 


\section{Figure 15}

\section{Effects of Macroeconomic and Projected Debt Variables on Forward-Looking Real Treasury Rate, VAR Analysis}

Response to Cholesky One S.D. Innovations \pm 2 S.E.

Response of Real Treasury Yield to

Real Oil Price

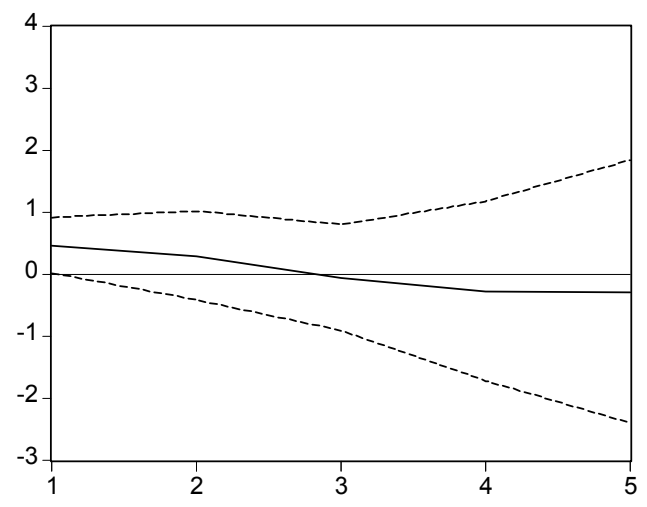

Response of Real Treasury Yield to

Federal Reserve Treasury Holdings

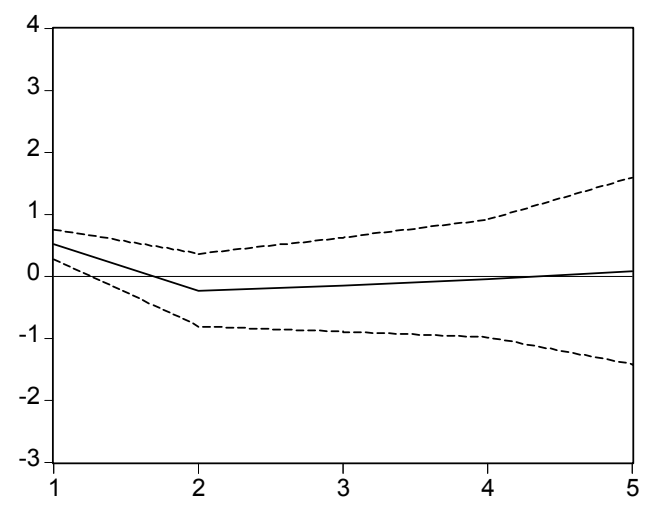

Response of Real Treasury Yield to Equity Premium

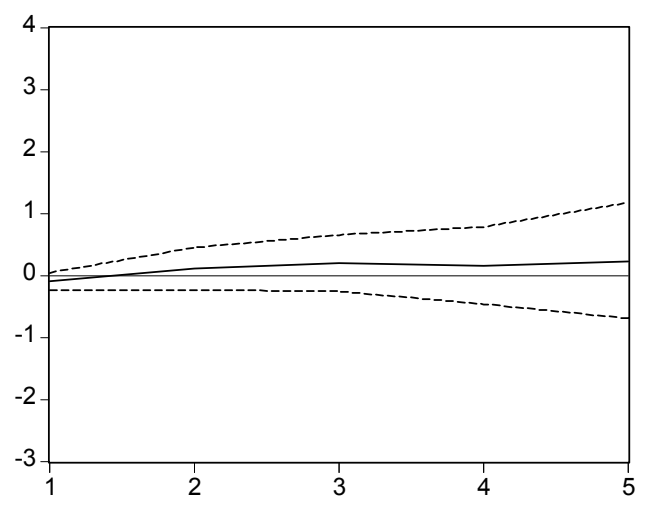

Response of Real Treasury Yield to Defense Shock

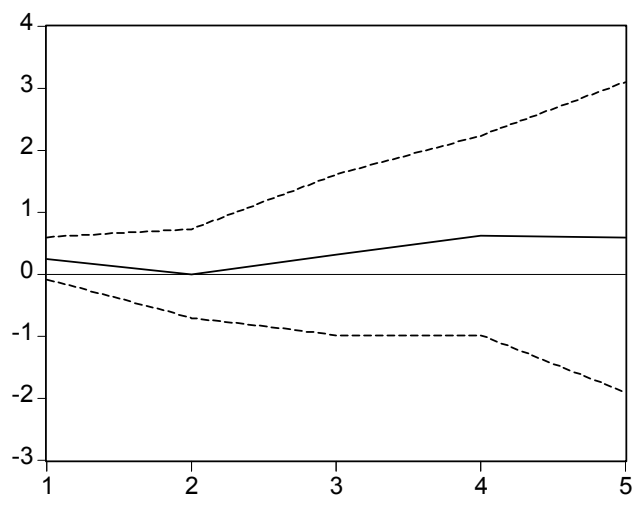

Response of Real Treasury Yield to Federal Debt

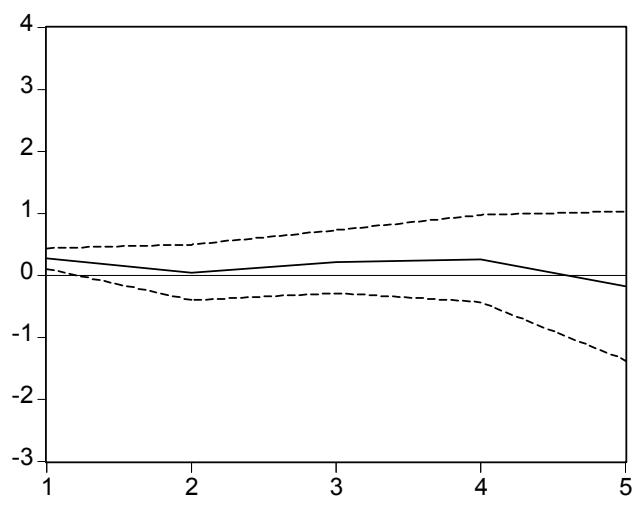

Response of Real Treasury Yield to Real GDP Growth

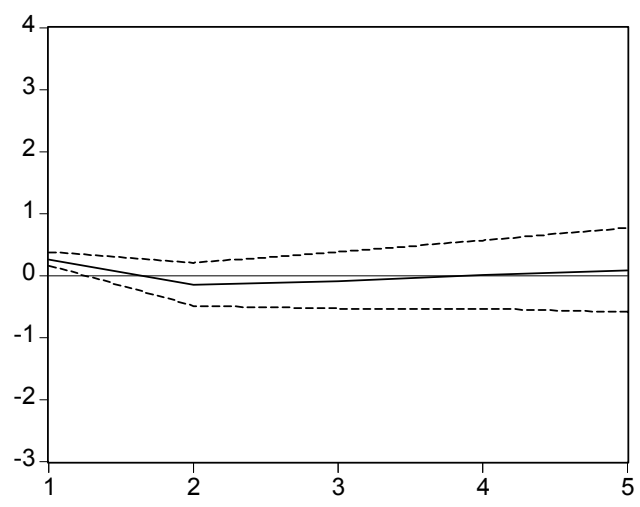




\section{Figure 16}

\section{Effects of Macroeconomic and Projected Deficit Variables on Forward-Looking Real Treasury Rate, VAR Analysis}

Response to Cholesky One S.D. Innovations \pm 2 S.E.

Response of Real Treasury Yield to Real Oil Price

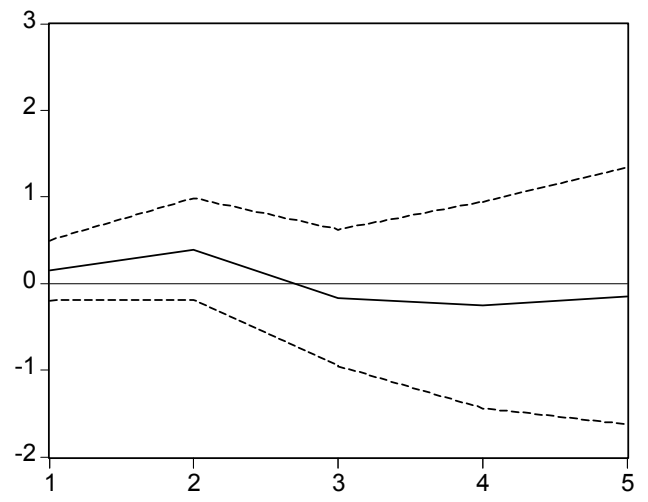

Response of Real Treasury Yield to Federal Reserve Treasury Purchases

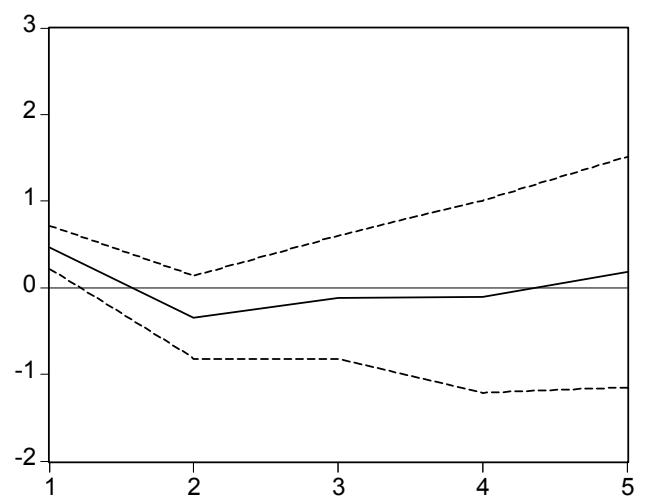

Response of Real Treasury Yield to Equity Premium

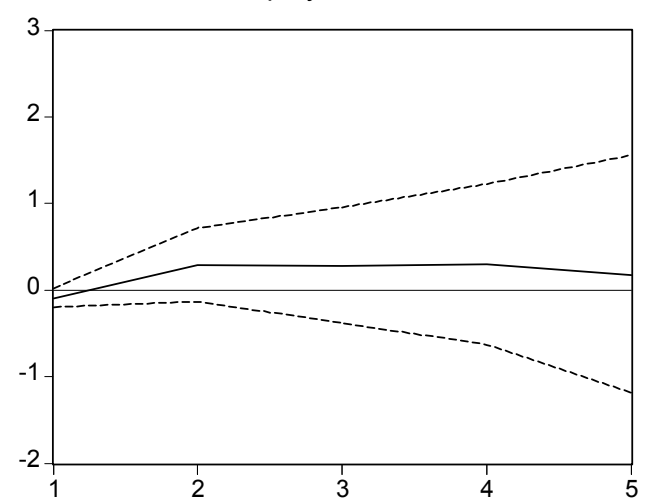

Response of Real Treasury Yield to Defense Shock

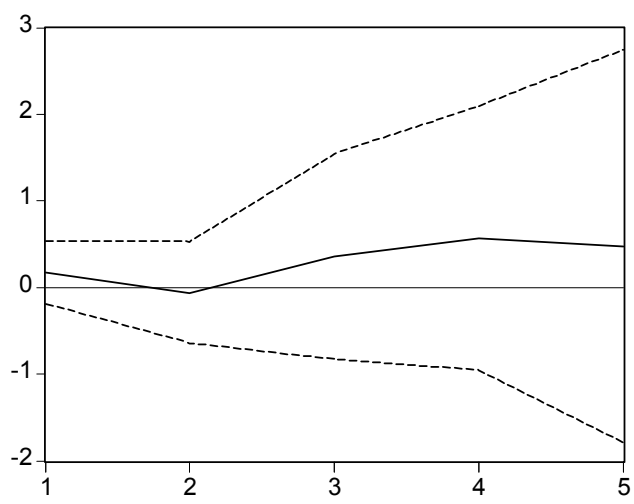

Response of Real Treasury Yield to Federal Deficit

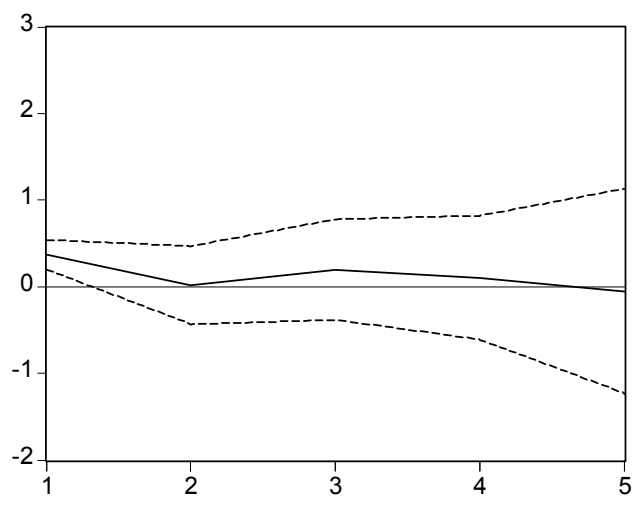

Response of Real Treasury Yield to Real GDP Growth

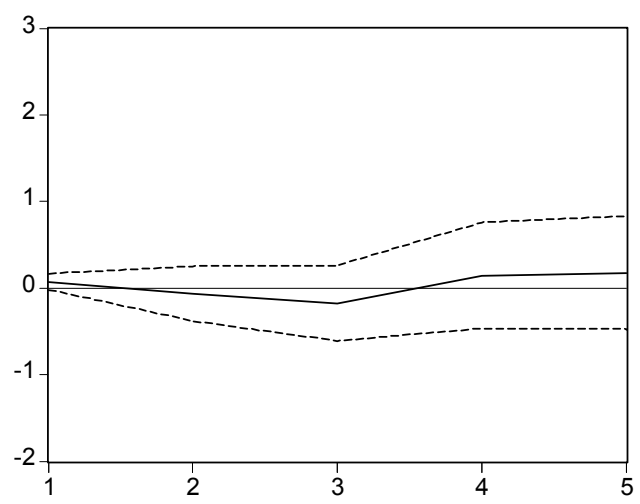




\section{Figure 17}

\section{Effects of Macroeconomic and Projected Debt Variables on Current Real Treasury Rate, \\ VAR Analysis}

Response to Cholesky One S.D. Innovations \pm 2 S.E.

Response of Real Treasury Yield to

Real Oil Price

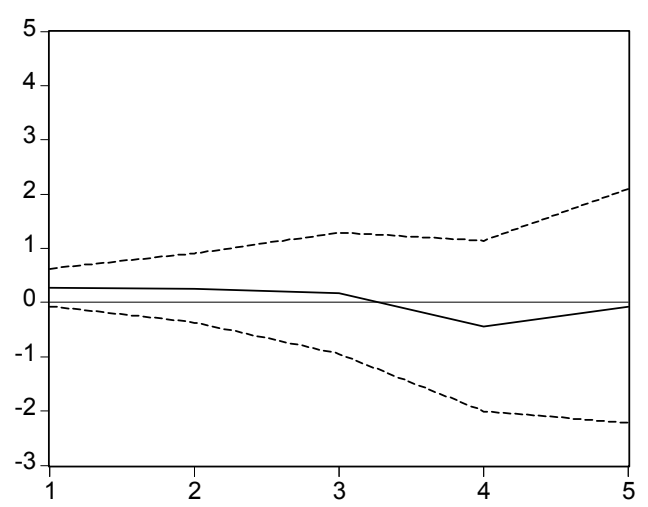

Response of Real Treasury Yield to

Federal Reserve Treasury Holdings

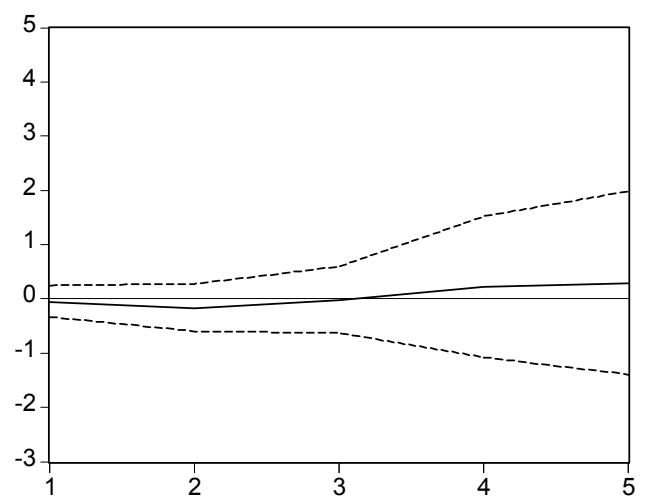

Response of Real Treasury Yield to Equity Premium

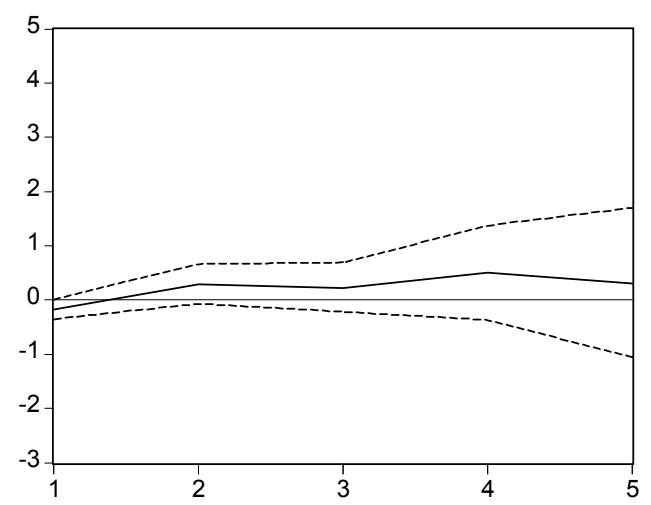

Response of Real Treasury Yield to Defense Shock

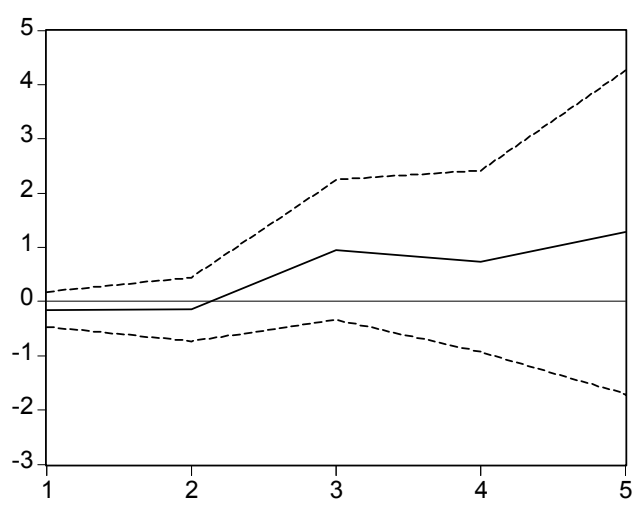

Response of Real Treasury Yield to Federal Debt

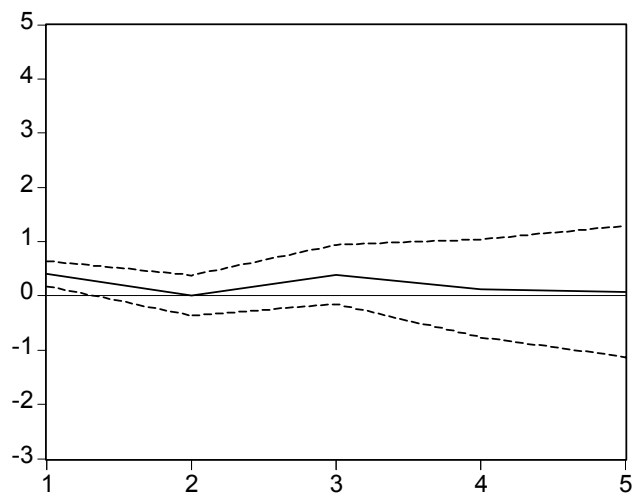

Response of Real Treasury Yield to Real GDP Growth

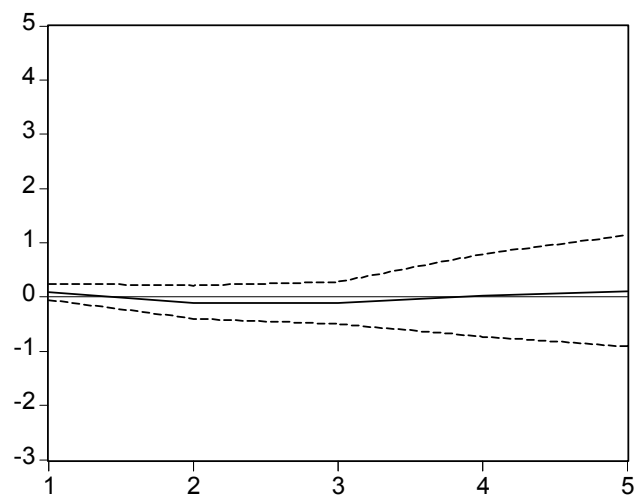




\section{Figure 18}

\section{Effects of Macroeconomic and Projected Deficit Variables on Current Real Treasury Rate, VAR Analysis}

Response to Cholesky One S.D. Innovations \pm 2 S.E.

Response of Real Treasury Yield to

Real Oil Price

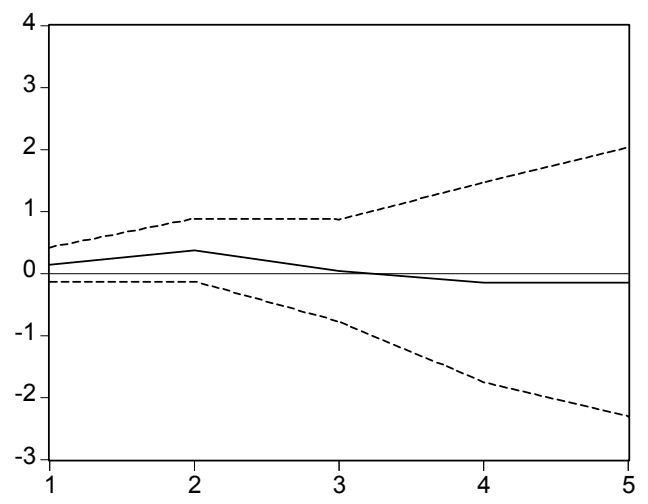

Response of Real Treasury Yield to Federal Reserve Treasury Purchases

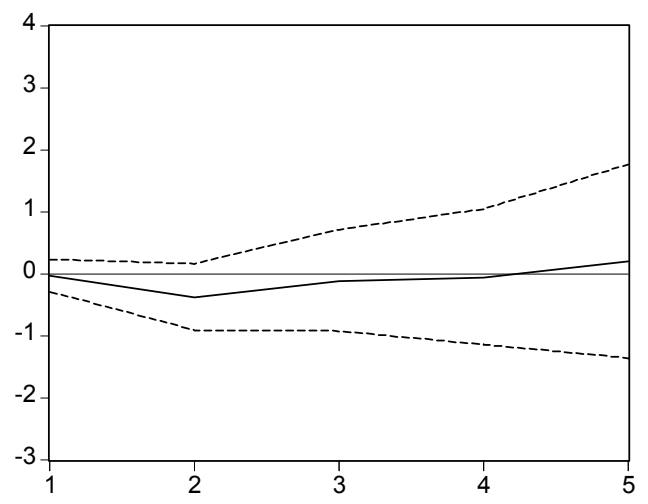

Response of Real Treasury Yield to Equity Premium

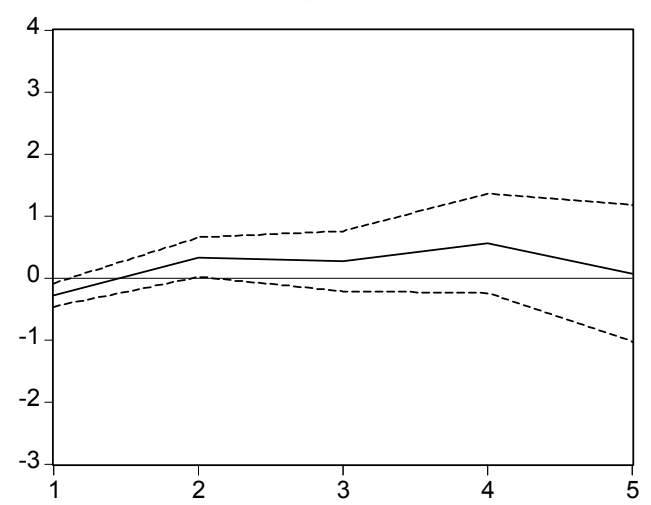

Response of Real Treasury Yield to Defense Shock

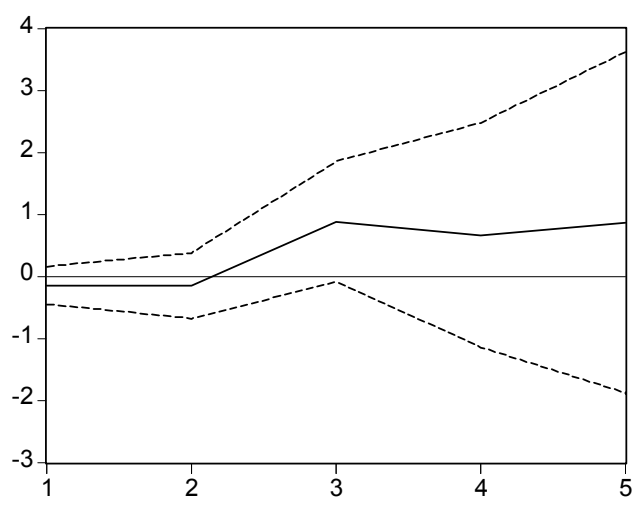

Response of Real Treasury Yield to Federal Deficit

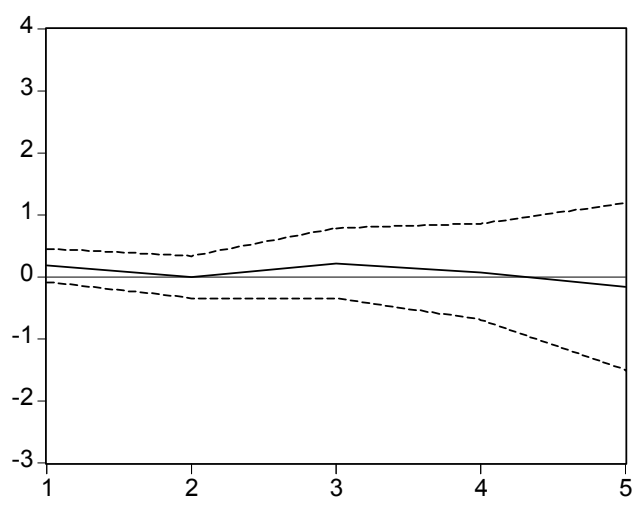

Response of Real Treasury Yield to Real GDP Growth

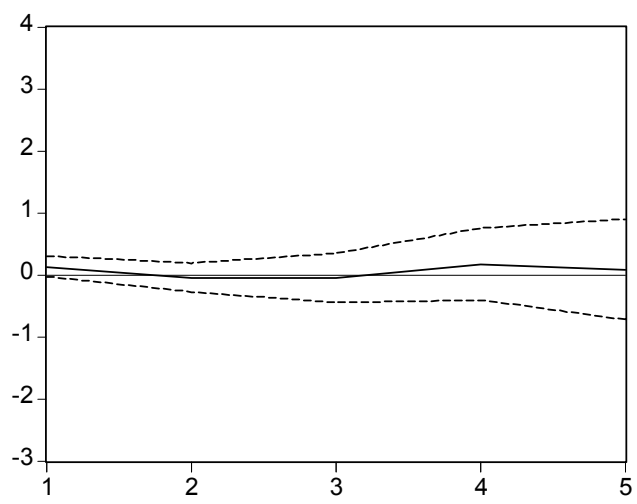




\section{Figure 19}

\section{Effects of Macroeconomic and Current Debt Variables on Current Real Treasury Rate, VAR Analysis}

Response to Cholesky One S.D. Innovations \pm 2 S.E.

Response of Real Treasury Yield to Real Oil Price

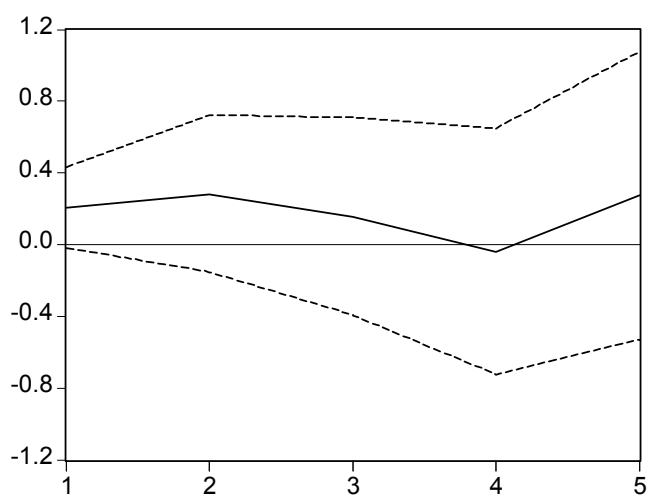

Response of Real Treasury Yield to Federal Reserve Treasury Holdings

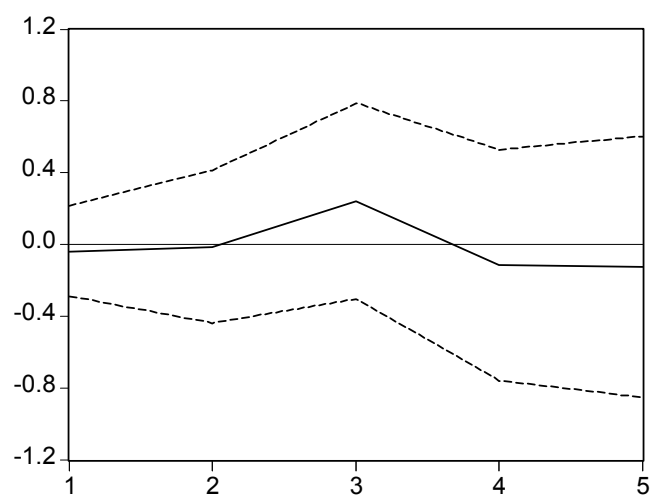

Response of Real Treasury Yield to Equity Premium

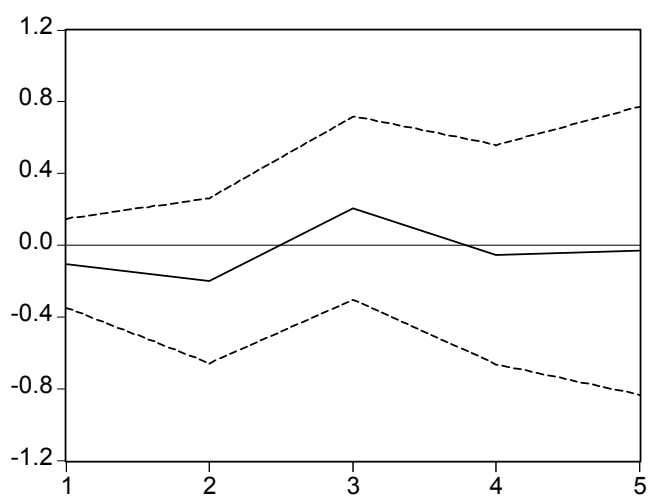

Response of Real Treasury Yield to Defense Shock

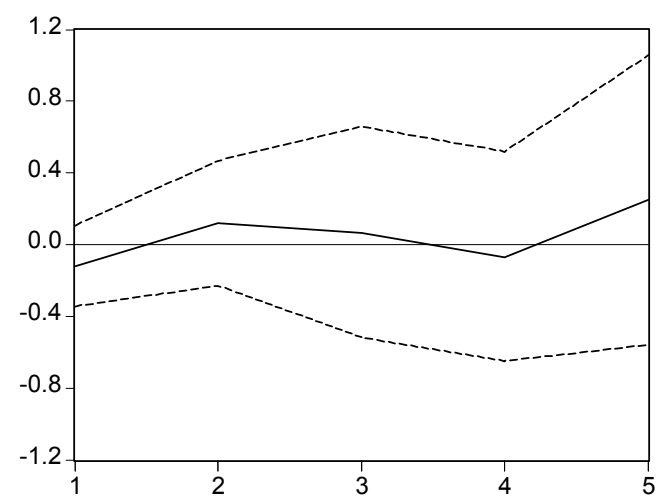

Response of Real Treasury Yield to Federal Debt

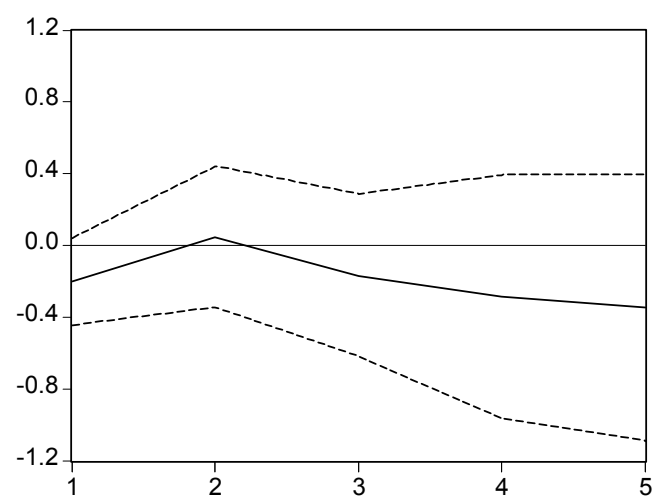

Response of Real Treasury Yield to Real GDP Growth

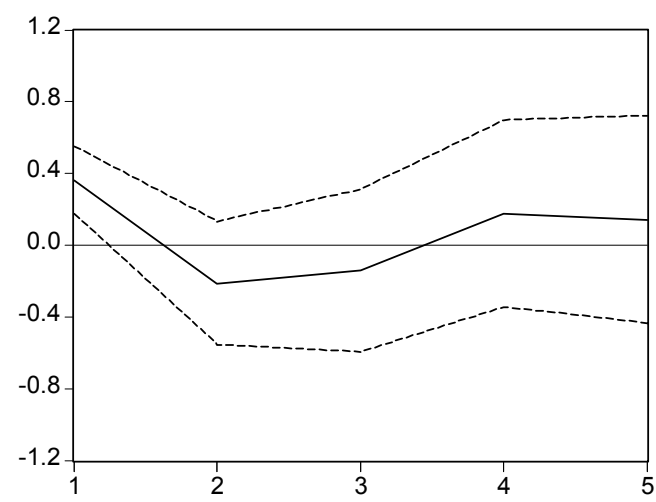


Figure 20

\section{Effects of Macroeconomic and Current Deficit Variables on Current Real Treasury Rate, VAR Analysis}

Response to Cholesky One S.D. Innovations \pm 2 S.E.

Response of Real Treasury Yield to Real Oil Price

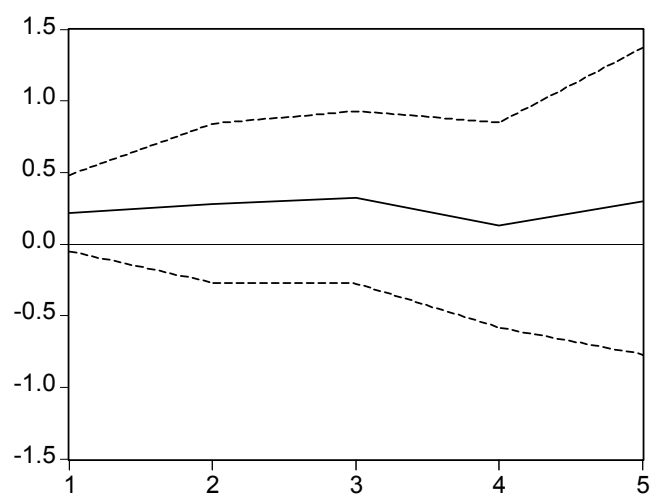

Response of Real Treasury Yield to Federal Reserve Treasury Purchases

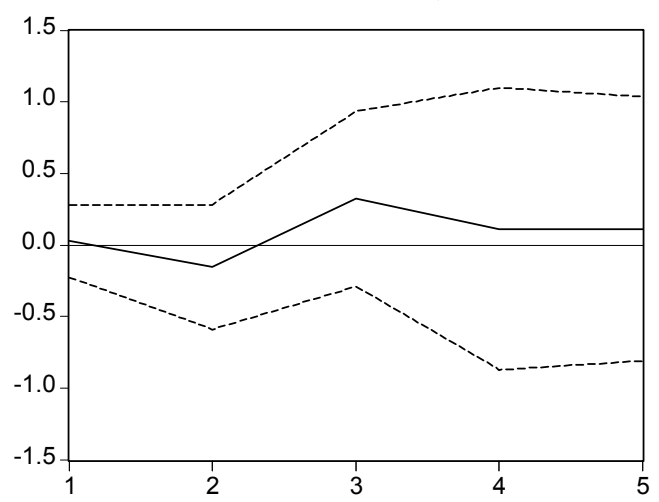

Response of Real Treasury Yield to Equity Premium

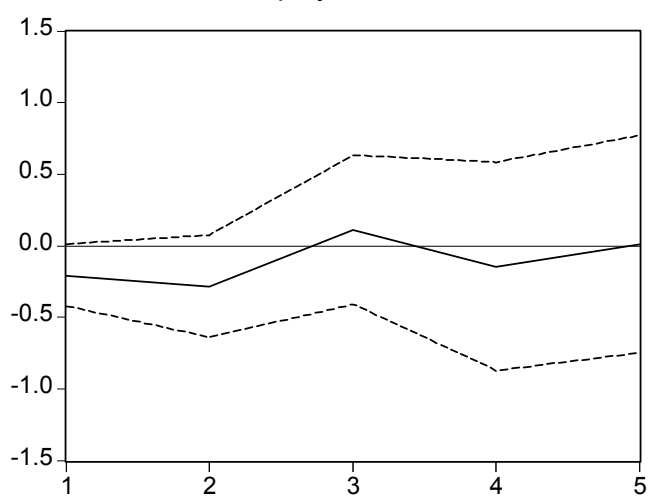

Response of Real Treasury Yield to Defense Shock

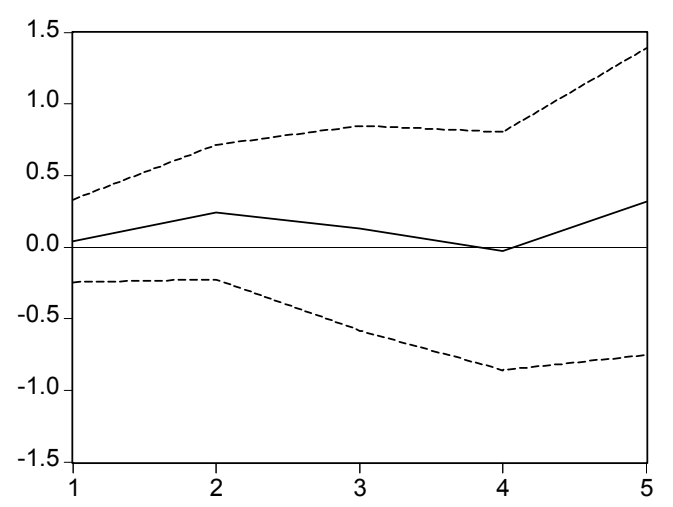

Response of Real Treasury Yield to Federal Borrowing

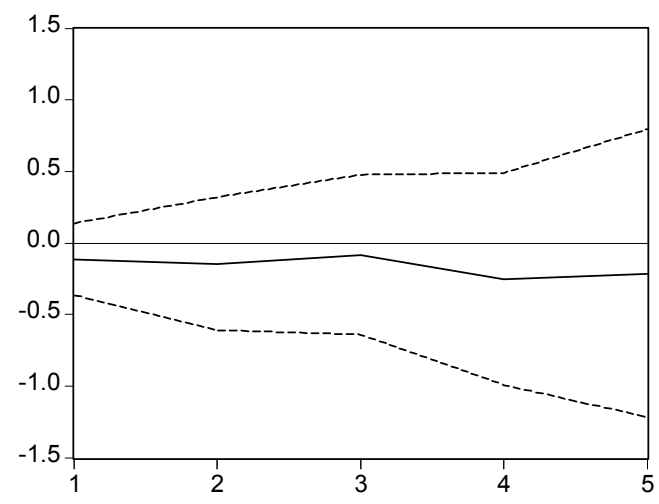

Response of Real Treasury Yield to Real GDP Growth

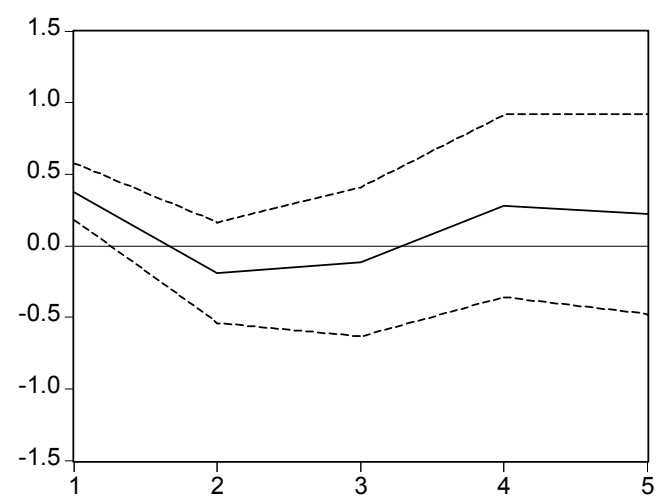




\section{Table 1}

Changes in Federal Government Debt and Interest Rates:

\section{Calculations from an Economic Model of Crowding Out}

Change in interest rates (basis points)

\begin{tabular}{|c|c|c|c|}
\hline $\begin{array}{c}\text { Increase in } \\
\text { Federal debt } \\
(\% \text { of GDP })\end{array}$ & $\begin{array}{c}\text { No offset } \\
\partial K / \partial D=-1 \\
(1)\end{array}$ & $\begin{array}{c}\mathbf{2 0 \%} \text { offset } \\
\partial K / \partial D=-0.8 \\
\text { (2) }\end{array}$ & $\begin{array}{c}\mathbf{4 0 \%} \text { offset } \\
\partial K / \partial D=-0.6 \\
\text { (3) }\end{array}$ \\
\hline 1) 1 percent & 2.4 & 1.9 & 1.4 \\
\hline 2) 5 percent & 11.8 & 9.5 & 7.1 \\
\hline 3) 10 percent & 23.7 & 18.9 & 14.2 \\
\hline $\begin{array}{c}\text { Eliminate } \\
\text { Federal Debt }\end{array}$ & & & \\
\hline 4) $\$ 4$ trillion & -86 & -69 & -52 \\
\hline
\end{tabular}


Table 2

Regression Results for Real Five-Year-Ahead Ten-Year Treasury Rate and CBO Five-Year-Ahead Federal Debt or Deficit Projections

(1976-2003)

\begin{tabular}{|c|c|c|c|}
\hline & \multicolumn{3}{|c|}{ Dependent Variable } \\
\hline & $\begin{array}{c}\text { (1) } \\
\text { Level of } \\
\text { Treasury Rate }\end{array}$ & $\begin{array}{c}(2) \\
\text { Change in } \\
\text { Treasury Rate }\end{array}$ & $\begin{array}{c}(3) \\
\text { Level of } \\
\text { Treasury rate }\end{array}$ \\
\hline Federal Debt/GDP & $\begin{array}{c}0.028 \\
(0.011)^{*}\end{array}$ & ---- & --- \\
\hline Federal Deficit/GDP & ---- & $\begin{array}{c}0.030 \\
(0.053)\end{array}$ & $\begin{array}{c}0.185 \\
(0.066)^{*}\end{array}$ \\
\hline Real GDP growth rate & $\begin{array}{l}-0.014 \\
(0.284) \\
\end{array}$ & --- & $\begin{array}{c}0.029 \\
(0.279)\end{array}$ \\
\hline $\begin{array}{l}\text { Change in } \\
\text { Real GDP growth rate }\end{array}$ & ---- & $\begin{array}{l}-0.851 \\
(0.246)\end{array}$ & --- \\
\hline Real Oil price & $\begin{array}{c}0.059 \\
(0.014)^{*}\end{array}$ & --- & $\begin{array}{c}0.049 \\
(0.021)^{*}\end{array}$ \\
\hline $\begin{array}{l}\text { Change in } \\
\text { Real Oil price }\end{array}$ & ---- & $\begin{array}{c}0.028 \\
(0.018)\end{array}$ & --- \\
\hline Equity premium & $\begin{array}{c}-0.269 \\
(0.134)^{*}\end{array}$ & --- & $\begin{array}{c}-0.279 \\
(0.105)^{*}\end{array}$ \\
\hline $\begin{array}{l}\text { Change in } \\
\text { Equity premium }\end{array}$ & ---- & $\begin{array}{l}-0.332 \\
(0.164)^{*}\end{array}$ & --- \\
\hline Defense shock & $\begin{array}{c}1.398 \\
(0.568)^{*}\end{array}$ & $\begin{array}{c}1.822 \\
(0.210)^{*}\end{array}$ & $\begin{array}{c}1.087 \\
(0.492)^{*}\end{array}$ \\
\hline $\begin{array}{l}\text { Federal Reserve } \\
\text { Treasury holdings }\end{array}$ & $\begin{array}{l}-0.410 \\
(0.197)^{*}\end{array}$ & & \\
\hline $\begin{array}{l}\text { Federal Reserve } \\
\text { Treasury purchases }\end{array}$ & ----- & $\begin{array}{l}-0.810 \\
(0.570)\end{array}$ & $\begin{array}{l}-0.521 \\
(0.629)\end{array}$ \\
\hline Constant & $\begin{array}{c}4.136 \\
(1.448)^{*}\end{array}$ & $\begin{array}{c}0.108 \\
(0.231)\end{array}$ & $\begin{array}{c}3.299 \\
(0.501)^{*}\end{array}$ \\
\hline Adjusted R-squared & 0.69 & 0.32 & 0.69 \\
\hline DW statistic & 2.52 & 2.90 & 2.39 \\
\hline $\mathrm{N}$ & 28 & 28 & 28 \\
\hline
\end{tabular}

Note: Newey-West standard errors in parentheses.

* = coefficient estimate significant at $10 \%$ level. 


\section{Table 3}

\section{Regression Results for Current Real Ten-Year Treasury Rate and CBO Five-Year-Ahead Federal Debt or Deficit Projections}

(1976-2003)

\begin{tabular}{|c|c|c|c|}
\hline & \multicolumn{3}{|c|}{ Dependent Variable } \\
\hline & $\begin{array}{c}\text { (1) } \\
\text { Level of } \\
\text { Treasury Rate }\end{array}$ & $\begin{array}{c}(2) \\
\text { Change in } \\
\text { Treasury Rate }\end{array}$ & $\begin{array}{c}\text { (3) } \\
\text { Level of } \\
\text { Treasury rate }\end{array}$ \\
\hline Federal Debt/GDP & $\begin{array}{c}0.033 \\
(0.013)^{*}\end{array}$ & ---- & ---- \\
\hline Federal Deficit/GDP & ---- & $\begin{array}{c}0.034 \\
(0.068)\end{array}$ & $\begin{array}{c}0.236 \\
(0.064)^{*}\end{array}$ \\
\hline Real GDP growth rate & $\begin{array}{l}-0.373 \\
(0.291) \\
\end{array}$ & --- & $\begin{array}{l}-0.266 \\
(0.347) \\
\end{array}$ \\
\hline $\begin{array}{l}\text { Change in } \\
\text { Real GDP growth rate }\end{array}$ & ---- & $\begin{array}{l}-0.607 \\
(0.417)\end{array}$ & --- \\
\hline Real Oil price & $\begin{array}{c}0.091 \\
(0.014)^{*}\end{array}$ & ---- & $\begin{array}{c}0.081 \\
(0.024)^{*}\end{array}$ \\
\hline $\begin{array}{l}\text { Change in } \\
\text { Real Oil price }\end{array}$ & --- & $\begin{array}{c}0.064 \\
(0.051)\end{array}$ & --- \\
\hline Equity premium & $\begin{array}{l}-0.376 \\
(0.134)^{*}\end{array}$ & ---- & $\begin{array}{l}-0.389 \\
(0.145)^{*}\end{array}$ \\
\hline $\begin{array}{l}\text { Change in } \\
\text { Equity premium }\end{array}$ & --- & $\begin{array}{l}-0.472 \\
(0.189)^{*}\end{array}$ & --- \\
\hline Defense shock & $\begin{array}{c}0.440 \\
(0.380)\end{array}$ & $\begin{array}{c}0.665 \\
(1.046)\end{array}$ & $\begin{array}{c}0.047 \\
(0.469)\end{array}$ \\
\hline $\begin{array}{l}\text { Federal Reserve } \\
\text { Treasury holdings }\end{array}$ & $\begin{array}{l}-0.668 \\
(0.260)^{*}\end{array}$ & & \\
\hline $\begin{array}{l}\text { Federal Reserve } \\
\text { Treasury purchases }\end{array}$ & ---- & $\begin{array}{l}-0.485 \\
(0.726)\end{array}$ & $\begin{array}{l}-1.064 \\
(0.587)^{*}\end{array}$ \\
\hline Constant & $\begin{array}{c}5.058 \\
(1.94)^{*}\end{array}$ & $\begin{array}{c}0.105 \\
(0.260)\end{array}$ & $\begin{array}{c}3.119 \\
(0.634)^{*}\end{array}$ \\
\hline Adjusted R-squared & 0.86 & 0.42 & 0.86 \\
\hline DW statistic & 1.68 & 2.90 & 1.68 \\
\hline $\mathrm{N}$ & 28 & 28 & 28 \\
\hline
\end{tabular}

Note: Newey-West standard errors in parentheses.

$*$ = coefficient estimate significant at $10 \%$ level. 
Table 4

\section{Regression Results for Current Real Ten-Year Treasury Rate and Current Federal Debt or Borrowing}

(1953-2003)

\begin{tabular}{|c|c|c|c|}
\hline & \multicolumn{3}{|c|}{ Dependent Variable } \\
\hline & $\begin{array}{c}\text { (1) } \\
\text { Level of } \\
\text { Treasury Rate }\end{array}$ & $\begin{array}{c}(2) \\
\text { Change in } \\
\text { Treasury Rate }\end{array}$ & $\begin{array}{c}\text { (3) } \\
\text { Level of } \\
\text { Treasury rate }\end{array}$ \\
\hline Federal Debt/GDP & $\begin{array}{c}0.047 \\
(0.036) \\
\end{array}$ & --- & --- \\
\hline Federal Deficit/GDP & ---- & $\begin{array}{c}0.071 \\
(0.066)\end{array}$ & $\begin{array}{c}0.091 \\
(0.107)\end{array}$ \\
\hline Real GDP growth rate & $\begin{array}{c}0.102 \\
(0.049)^{*}\end{array}$ & --- & $\begin{array}{c}0.112 \\
(0.040)^{*}\end{array}$ \\
\hline $\begin{array}{l}\text { Change in } \\
\text { Real GDP growth rate }\end{array}$ & ---- & $\begin{array}{c}0.100 \\
(0.035)^{*}\end{array}$ & ---- \\
\hline Real Oil price & $\begin{array}{c}0.101 \\
(0.043)^{*}\end{array}$ & ---- & $\begin{array}{c}0.099 \\
(0.039)^{*}\end{array}$ \\
\hline $\begin{array}{l}\text { Change in } \\
\text { Real Oil price }\end{array}$ & ---- & $\begin{array}{c}0.115 \\
(0.042)^{*}\end{array}$ & ---- \\
\hline Equity premium & $\begin{array}{l}-0.224 \\
(0.297)\end{array}$ & ---- & $\begin{array}{l}-0.135 \\
(0.286)\end{array}$ \\
\hline $\begin{array}{l}\text { Change in } \\
\text { Equity premium }\end{array}$ & ---- & $\begin{array}{l}-0.091 \\
(0.302)\end{array}$ & --- \\
\hline Defense shock & $\begin{array}{l}-0.425 \\
(0.349)\end{array}$ & $\begin{array}{l}-0.195 \\
(0.412)\end{array}$ & $\begin{array}{l}-0.515 \\
(0.321)\end{array}$ \\
\hline $\begin{array}{l}\text { Federal Reserve } \\
\text { Treasury holdings }\end{array}$ & $\begin{array}{l}-0.401 \\
(0.525) \\
\end{array}$ & & \\
\hline $\begin{array}{l}\text { Federal Reserve } \\
\text { Treasury purchases }\end{array}$ & ---- & $\begin{array}{c}0.259 \\
(0.544)\end{array}$ & $\begin{array}{c}0.500 \\
(0.496)\end{array}$ \\
\hline Constant & $\begin{array}{c}1.976 \\
(4.407) \\
\end{array}$ & $\begin{array}{l}-0.263 \\
(0.192)\end{array}$ & $\begin{array}{c}1.017 \\
(1.084)\end{array}$ \\
\hline $\operatorname{AR}(1)$ & $\begin{array}{c}0.521 \\
(0.128)^{*}\end{array}$ & & \\
\hline Adjusted R-squared & 0.60 & 0.21 & 0.59 \\
\hline DW statistic & 2.02 & 2.56 & 2.13 \\
\hline $\mathrm{N}$ & 50 & 50 & 50 \\
\hline
\end{tabular}

Note: Newey-West standard errors in parentheses.

$*=$ coefficient estimate significant at $10 \%$ level. 
Table 5

Variance Decomposition of Five-Year-Ahead Ten-Year Treasury Rate

(corresponds to impulse responses in Figure 15)

\begin{tabular}{|c|c|c|c|c|c|c|c|c|}
\hline Period & S.E. & $\begin{array}{c}\text { Oil } \\
\text { Price } \\
\end{array}$ & $\begin{array}{c}\text { Defense } \\
\text { Shock } \\
\end{array}$ & $\begin{array}{c}\text { Federal Reserve } \\
\text { Treasury } \\
\text { Holdings } \\
\end{array}$ & $\begin{array}{c}\text { Projected } \\
\text { Federal Debt } \\
\end{array}$ & $\begin{array}{c}\text { Equity } \\
\text { Premium } \\
\end{array}$ & $\begin{array}{l}\text { Projected } \\
\text { Real GDP } \\
\text { Growth }\end{array}$ & $\begin{array}{c}\text { Forward-Looking } \\
\text { Real Treasury } \\
\text { Yield } \\
\end{array}$ \\
\hline 1 & 4.50 & $\begin{array}{c}30.26 \\
(16.28)\end{array}$ & $\begin{array}{c}8.27 \\
(10.13)\end{array}$ & $\begin{array}{c}36.82 \\
(12.60)\end{array}$ & $\begin{array}{l}10.05 \\
(6.09)\end{array}$ & $\begin{array}{c}1.39 \\
(1.67)\end{array}$ & $\begin{array}{l}9.65 \\
(4.16)\end{array}$ & $\begin{array}{l}3.56 \\
(1.24)\end{array}$ \\
\hline 2 & 6.29 & $\begin{array}{c}33.78 \\
(16.22)\end{array}$ & $\begin{array}{l}6.62 \\
(9.52)\end{array}$ & $\begin{array}{c}35.73 \\
(12.95)\end{array}$ & $\begin{array}{l}8.23 \\
(5.70)\end{array}$ & $\begin{array}{l}2.32 \\
(5.20)\end{array}$ & $\begin{array}{l}10.29 \\
(5.25)\end{array}$ & $\begin{array}{l}3.02 \\
(1.41)\end{array}$ \\
\hline 3 & 6.88 & $\begin{array}{l}27.45 \\
(14.29)\end{array}$ & $\begin{array}{c}14.04 \\
(17.39)\end{array}$ & $\begin{array}{l}30.73 \\
(12.22)\end{array}$ & $\begin{array}{l}10.81 \\
(6.91)\end{array}$ & $\begin{array}{c}5.12 \\
(5.15)\end{array}$ & $\begin{array}{l}8.99 \\
(4.53)\end{array}$ & $\begin{array}{c}2.87 \\
(2.06)\end{array}$ \\
\hline 4 & 7.60 & $\begin{array}{l}23.22 \\
(15.33)\end{array}$ & $\begin{array}{l}32.01 \\
(16.17)\end{array}$ & $\begin{array}{l}20.53 \\
(12.13)\end{array}$ & $\begin{array}{l}11.14 \\
(5.91)\end{array}$ & $\begin{array}{l}4.91 \\
(4.48)\end{array}$ & $\begin{array}{l}5.97 \\
(4.29)\end{array}$ & $\begin{array}{l}2.21 \\
(1.71)\end{array}$ \\
\hline 5 & 8.41 & $\begin{array}{l}21.58 \\
(13.77) \\
\end{array}$ & $\begin{array}{c}40.13 \\
(17.43) \\
\end{array}$ & $\begin{array}{r}15.83 \\
(12.84) \\
\end{array}$ & $\begin{array}{l}9.86 \\
(6.40) \\
\end{array}$ & $\begin{array}{c}6.12 \\
(4.61) \\
\end{array}$ & $\begin{array}{l}4.80 \\
(4.42) \\
\end{array}$ & $\begin{array}{c}1.68 \\
(1.47) \\
\end{array}$ \\
\hline \multicolumn{9}{|c|}{$\begin{array}{l}\text { Cholesky Ordering: Oil Price, Defense Shock, F } \\
\text { Forward-Looking Real Treasury Yield } \\
\text { Standard Errors: Monte Carlo (100 repetitions) }\end{array}$} \\
\hline
\end{tabular}


Table 6

Variance Decomposition of Five-Year-Ahead Ten-Year Treasury Rate

(corresponds to impulse responses in Figure 16)

\begin{tabular}{|c|c|c|c|c|c|c|c|c|}
\hline Period & S.E. & $\begin{array}{c}\text { Oil } \\
\text { Price } \\
\end{array}$ & $\begin{array}{l}\text { Defense } \\
\text { Shock }\end{array}$ & $\begin{array}{c}\text { Federal Reserve } \\
\text { Treasury } \\
\text { Purchases } \\
\end{array}$ & $\begin{array}{c}\text { Projected } \\
\text { Federal Deficit }\end{array}$ & $\begin{array}{c}\text { Equity } \\
\text { Premium } \\
\end{array}$ & $\begin{array}{l}\text { Projected } \\
\text { Real GDP } \\
\text { Growth }\end{array}$ & $\begin{array}{l}\text { Forward-Looking } \\
\text { Real Treasury } \\
\text { Yield } \\
\end{array}$ \\
\hline 1 & 3.88 & $\begin{array}{l}4.79 \\
(8.77)\end{array}$ & $\begin{array}{l}6.11 \\
(8.29)\end{array}$ & $\begin{array}{l}45.68 \\
(14.05)\end{array}$ & $\begin{array}{l}28.35 \\
(10.09)\end{array}$ & $\begin{array}{c}1.92 \\
(2.20)\end{array}$ & $\begin{array}{l}1.04 \\
(1.85)\end{array}$ & $\begin{array}{l}12.10 \\
(4.74)\end{array}$ \\
\hline 2 & 7.04 & $\begin{array}{l}21.32 \\
(13.70)\end{array}$ & $\begin{array}{l}3.92 \\
(8.13)\end{array}$ & $\begin{array}{l}39.76 \\
(10.23)\end{array}$ & $\begin{array}{l}16.01 \\
(6.91)\end{array}$ & $\begin{array}{l}10.98 \\
(9.70)\end{array}$ & $\begin{array}{l}1.18 \\
(3.24)\end{array}$ & $\begin{array}{l}6.82 \\
(3.12)\end{array}$ \\
\hline 3 & 7.77 & $\begin{array}{c}17.95 \\
(12.79)\end{array}$ & $\begin{array}{c}13.98 \\
(14.57)\end{array}$ & $\begin{array}{l}29.91 \\
(9.84)\end{array}$ & $\begin{array}{l}14.71 \\
(7.73)\end{array}$ & $\begin{array}{l}14.67 \\
(8.30)\end{array}$ & $\begin{array}{l}3.63 \\
(3.56)\end{array}$ & $\begin{array}{l}5.14 \\
(3.15)\end{array}$ \\
\hline 4 & 8.27 & $\begin{array}{c}16.22 \\
(12.30)\end{array}$ & $\begin{array}{l}29.02 \\
(17.78)\end{array}$ & $\begin{array}{l}21.39 \\
(9.35)\end{array}$ & $\begin{array}{l}10.77 \\
(6.76)\end{array}$ & $\begin{array}{l}15.30 \\
(8.53)\end{array}$ & $\begin{array}{l}3.67 \\
(2.79)\end{array}$ & $\begin{array}{l}3.63 \\
(2.70)\end{array}$ \\
\hline 5 & 8.91 & $\begin{array}{c}14.51 \\
(12.40) \\
\end{array}$ & $\begin{array}{l}35.21 \\
(17.08) \\
\end{array}$ & $\begin{array}{l}19.29 \\
(8.11) \\
\end{array}$ & $\begin{array}{r}9.07 \\
(8.79) \\
\end{array}$ & $\begin{array}{l}14.21 \\
(7.94) \\
\end{array}$ & $\begin{array}{l}4.51 \\
(3.86) \\
\end{array}$ & $\begin{array}{l}3.20 \\
(2.83) \\
\end{array}$ \\
\hline \multicolumn{9}{|c|}{$\begin{array}{l}\text { Cholesky Ordering: Oil Price, Defense Shock, F } \\
\text { Forward-Looking Real Treasury Yield } \\
\text { Standard Errors: Monte Carlo (100 repetitions) }\end{array}$} \\
\hline
\end{tabular}


Table 7

Variance Decomposition of Current Ten-Year Treasury Rate

(corresponds to impulse responses in Figure 17)

\begin{tabular}{|c|c|c|c|c|c|c|c|c|}
\hline Period & S.E. & $\begin{array}{c}\text { Oil } \\
\text { Price } \\
\end{array}$ & $\begin{array}{l}\text { Defense } \\
\text { Shock }\end{array}$ & $\begin{array}{l}\text { eral Reser } \\
\text { Treasury } \\
\text { Holdings }\end{array}$ & $\begin{array}{c}\text { Projected } \\
\text { Federal Debt }\end{array}$ & $\begin{array}{c}\text { Equity } \\
\text { Premium }\end{array}$ & $\begin{array}{c}\text { Projected } \\
\text { Real GDP } \\
\text { Growth }\end{array}$ & $\begin{array}{c}\text { Current } \\
\text { Real Treasury } \\
\text { Yield } \\
\end{array}$ \\
\hline 1 & 5.12 & $\begin{array}{c}16.84 \\
(13.88)\end{array}$ & $\begin{array}{l}5.67 \\
(7.98)\end{array}$ & $\begin{array}{l}0.65 \\
(5.39)\end{array}$ & $\begin{array}{l}37.42 \\
(13.96)\end{array}$ & $\begin{array}{l}7.09 \\
(7.63)\end{array}$ & $\begin{array}{l}1.91 \\
(3.29)\end{array}$ & $\begin{array}{l}30.41 \\
(10.28)\end{array}$ \\
\hline 2 & 6.44 & $\begin{array}{l}21.01 \\
(15.97)\end{array}$ & $\begin{array}{l}7.02 \\
(9.09)\end{array}$ & $\begin{array}{l}4.91 \\
(8.29)\end{array}$ & $\begin{array}{l}24.25 \\
(9.60)\end{array}$ & $\begin{array}{l}17.08 \\
(9.87)\end{array}$ & $\begin{array}{l}2.93 \\
(3.81)\end{array}$ & $\begin{array}{l}22.78 \\
(7.90)\end{array}$ \\
\hline 3 & 6.94 & $\begin{array}{c}9.10 \\
(16.54)\end{array}$ & $\begin{array}{l}52.38 \\
(19.78)\end{array}$ & $\begin{array}{l}1.81 \\
(6.64)\end{array}$ & $\begin{array}{l}16.84 \\
(8.12)\end{array}$ & $\begin{array}{l}9.07 \\
(5.77)\end{array}$ & $\begin{array}{l}1.78 \\
(3.55)\end{array}$ & $\begin{array}{l}9.02 \\
(4.74)\end{array}$ \\
\hline 4 & 8.22 & $\begin{array}{c}12.44 \\
(15.49)\end{array}$ & $\begin{array}{l}51.65 \\
(17.04)\end{array}$ & $\begin{array}{l}2.73 \\
(6.06)\end{array}$ & $\begin{array}{l}11.20 \\
(7.59)\end{array}$ & $\begin{array}{l}14.34 \\
(8.71)\end{array}$ & $\begin{array}{l}1.15 \\
(3.61)\end{array}$ & $\begin{array}{l}6.50 \\
(3.77)\end{array}$ \\
\hline 5 & 9.48 & $\begin{array}{c}7.54 \\
(13.49) \\
\end{array}$ & $\begin{array}{l}64.47 \\
(16.53) \\
\end{array}$ & $\begin{array}{l}3.40 \\
(5.53) \\
\end{array}$ & $\begin{array}{l}6.80 \\
(6.74) \\
\end{array}$ & $\begin{array}{l}10.53 \\
(7.03)\end{array}$ & $\begin{array}{l}0.92 \\
(3.86)\end{array}$ & $\begin{array}{l}6.34 \\
(4.78)\end{array}$ \\
\hline
\end{tabular}


Table 8

Variance Decomposition of Current Ten-Year Treasury Rate

(corresponds to impulse responses in Figure 18)

\begin{tabular}{|c|c|c|c|c|c|c|c|c|}
\hline Period & S.E. & $\begin{array}{c}\text { Oil } \\
\text { Price } \\
\end{array}$ & $\begin{array}{c}\text { Defense } \\
\text { Shock }\end{array}$ & $\begin{array}{c}\text { Federal Reserve } \\
\text { Treasury } \\
\text { Purchases } \\
\end{array}$ & $\begin{array}{c}\text { Projected } \\
\text { Federal Deficit }\end{array}$ & $\begin{array}{c}\text { Equity } \\
\text { Premium } \\
\end{array}$ & $\begin{array}{l}\text { Projected } \\
\text { Real GDP } \\
\text { Growth } \\
\end{array}$ & $\begin{array}{c}\text { Current } \\
\text { Real Treasury } \\
\text { Yield } \\
\end{array}$ \\
\hline 1 & 4.30 & $\begin{array}{l}5.80 \\
(10.18)\end{array}$ & $\begin{array}{l}7.29 \\
(8.22)\end{array}$ & $\begin{array}{l}0.34 \\
(4.69)\end{array}$ & $\begin{array}{l}10.26 \\
(8.45)\end{array}$ & $\begin{array}{l}24.80 \\
(11.53)\end{array}$ & $\begin{array}{l}5.29 \\
(5.69)\end{array}$ & $\begin{array}{l}46.21 \\
(10.96)\end{array}$ \\
\hline 2 & 7.11 & $\begin{array}{l}20.56 \\
(17.06)\end{array}$ & $\begin{array}{l}6.40 \\
(7.52)\end{array}$ & $\begin{array}{l}20.19 \\
(12.98)\end{array}$ & $\begin{array}{l}4.31 \\
(6.25)\end{array}$ & $\begin{array}{l}24.55 \\
(10.04)\end{array}$ & $\begin{array}{l}2.54 \\
(3.40)\end{array}$ & $\begin{array}{l}21.45 \\
(6.19)\end{array}$ \\
\hline 3 & 8.00 & $\begin{array}{c}9.35 \\
(14.16)\end{array}$ & $\begin{array}{l}49.35 \\
(19.53)\end{array}$ & $\begin{array}{l}9.98 \\
(9.32)\end{array}$ & $\begin{array}{l}4.51 \\
(5.68)\end{array}$ & $\begin{array}{l}15.37 \\
(7.67)\end{array}$ & $\begin{array}{l}1.34 \\
(3.24)\end{array}$ & $\begin{array}{l}10.10 \\
(3.87)\end{array}$ \\
\hline 4 & 8.33 & $\begin{array}{l}7.27 \\
(11.94)\end{array}$ & $\begin{array}{l}50.87 \\
(17.68)\end{array}$ & $\begin{array}{c}6.90 \\
(10.14)\end{array}$ & $\begin{array}{l}3.26 \\
(5.51)\end{array}$ & $\begin{array}{l}22.84 \\
(9.76)\end{array}$ & $\begin{array}{l}2.03 \\
(3.57)\end{array}$ & $\begin{array}{l}6.83 \\
(3.77)\end{array}$ \\
\hline 5 & 8.92 & $\begin{array}{c}5.99 \\
(12.05) \\
\end{array}$ & $\begin{array}{l}59.25 \\
(15.99) \\
\end{array}$ & $\begin{array}{l}6.19 \\
(9.99) \\
\end{array}$ & $\begin{array}{l}3.26 \\
(7.92) \\
\end{array}$ & $\begin{array}{l}16.84 \\
(7.07) \\
\end{array}$ & $\begin{array}{l}1.68 \\
(3.02) \\
\end{array}$ & $\begin{array}{l}6.79 \\
(3.39) \\
\end{array}$ \\
\hline
\end{tabular}


Table 9

Variance Decomposition of Current Ten-Year Treasury Rate

(corresponds to impulse responses in Figure 19)

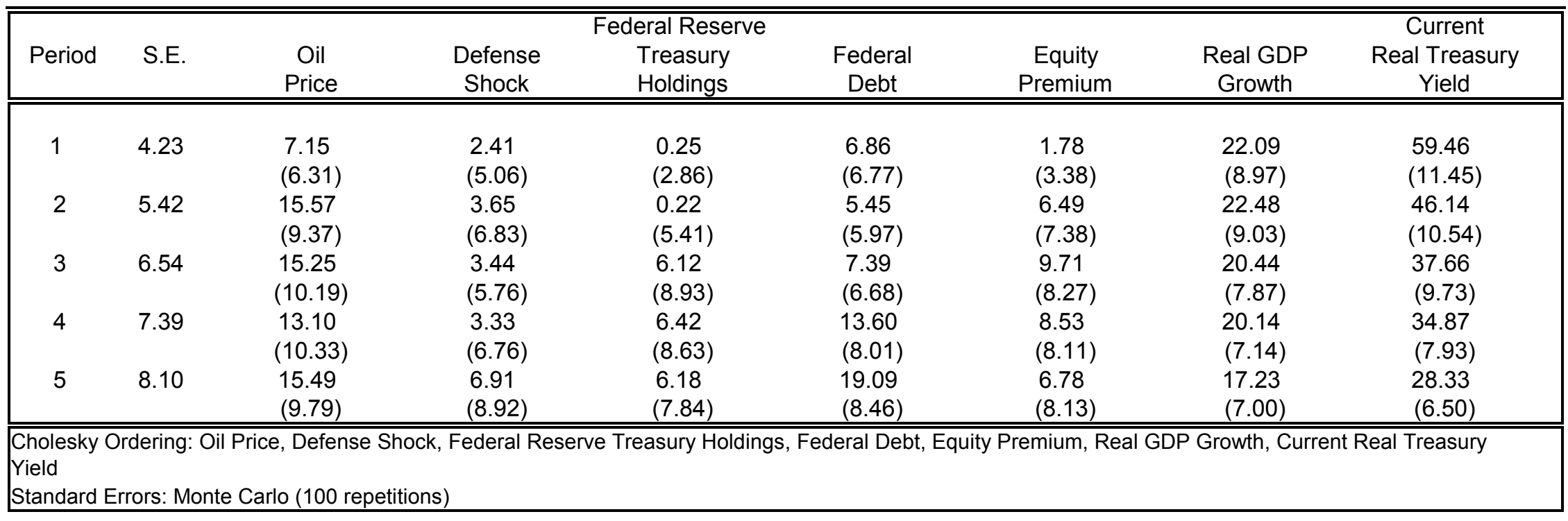


Table 10

Variance Decomposition of Current Ten-Year Treasury Rate

(corresponds to impulse responses in Figure 20)

\begin{tabular}{|c|c|c|c|c|c|c|c|c|}
\hline Period & S.E. & $\begin{array}{c}\text { Oil } \\
\text { Price } \\
\end{array}$ & $\begin{array}{c}\text { Defense } \\
\text { Shock }\end{array}$ & $\begin{array}{c}\text { Federal Reserve } \\
\text { Treasury } \\
\text { Purchases } \\
\end{array}$ & $\begin{array}{c}\text { Federal } \\
\text { Borrowing }\end{array}$ & $\begin{array}{c}\text { Equity } \\
\text { Premium }\end{array}$ & $\begin{array}{c}\text { Real GDP } \\
\text { Growth }\end{array}$ & $\begin{array}{c}\text { Current } \\
\text { Real Treasury } \\
\text { Yield } \\
\end{array}$ \\
\hline 1 & 4.72 & $\begin{array}{l}7.17 \\
(7.85)\end{array}$ & $\begin{array}{l}0.25 \\
(3.39)\end{array}$ & $\begin{array}{l}0.12 \\
(3.71)\end{array}$ & $\begin{array}{l}2.07 \\
(3.68)\end{array}$ & $\begin{array}{l}6.70 \\
(7.05)\end{array}$ & $\begin{array}{l}22.07 \\
(8.69)\end{array}$ & $\begin{array}{l}61.62 \\
(9.88)\end{array}$ \\
\hline 2 & 6.19 & $\begin{array}{l}12.99 \\
(11.01)\end{array}$ & $\begin{array}{l}6.32 \\
(7.94)\end{array}$ & $\begin{array}{l}2.60 \\
(6.52)\end{array}$ & $\begin{array}{l}3.63 \\
(6.43)\end{array}$ & $\begin{array}{l}13.04 \\
(9.31)\end{array}$ & $\begin{array}{l}18.56 \\
(6.87)\end{array}$ & $\begin{array}{l}42.86 \\
(9.35)\end{array}$ \\
\hline 3 & 6.99 & $\begin{array}{l}18.71 \\
(12.79)\end{array}$ & $\begin{array}{l}6.27 \\
(9.39)\end{array}$ & $\begin{array}{l}10.46 \\
(8.00)\end{array}$ & $\begin{array}{l}3.43 \\
(6.46)\end{array}$ & $\begin{array}{l}11.25 \\
(7.06)\end{array}$ & $\begin{array}{l}15.69 \\
(6.07)\end{array}$ & $\begin{array}{l}34.20 \\
(7.79)\end{array}$ \\
\hline 4 & 7.47 & $\begin{array}{c}16.51 \\
(11.29)\end{array}$ & $\begin{array}{l}5.22 \\
(8.63)\end{array}$ & $\begin{array}{l}9.41 \\
(9.13)\end{array}$ & $\begin{array}{l}7.17 \\
(7.70)\end{array}$ & $\begin{array}{l}10.73 \\
(6.40)\end{array}$ & $\begin{array}{l}18.05 \\
(6.16)\end{array}$ & $\begin{array}{l}32.91 \\
(7.16)\end{array}$ \\
\hline 5 & 7.82 & $\begin{array}{c}18.65 \\
(11.13)\end{array}$ & $\begin{array}{c}9.94 \\
(11.15) \\
\end{array}$ & $\begin{array}{l}8.52 \\
(8.25) \\
\end{array}$ & $\begin{array}{l}8.52 \\
(7.50) \\
\end{array}$ & $\begin{array}{l}8.91 \\
(6.39) \\
\end{array}$ & $\begin{array}{l}17.70 \\
(6.91) \\
\end{array}$ & $\begin{array}{l}27.76 \\
(6.37) \\
\end{array}$ \\
\hline
\end{tabular}

